
6

\title{
Effect of limited enzymatic hydrolysis on structure and emulsifying properties of rice glutelin
}

\section{Xingfeng $\mathrm{Xu}^{\mathrm{a}, \mathrm{b}}$, Wei Liu ${ }^{\mathrm{a}}$, Chengmei Liu ${ }^{\mathrm{a}, \mathrm{H}^{*}}$, Liping Luo ${ }^{\mathrm{a}}$, Jun Chen ${ }^{\mathrm{a}}$,} Shunjing Luo ${ }^{a}$, David Julian McClements ${ }^{\mathrm{b}, c, 1 * *}$, Lixin $\mathrm{Wu}^{\mathrm{d}}$ (1)

${ }^{a}$ State Key Laboratory of Food Science and Technology, Nanchang University, Nanchang, No. 235 Nanjing East Road, Nanchang 330047, Jiangxi, China. ${ }^{b}$ Department of Food Science, University of Massachusetts, Amherst, MA 01003, USA. ${ }^{c}$ Department of Biochemistry, Faculty of Science, King Abdulaziz University, P. O. Box 80203, Jeddah, 21589, Saudi Arabia

${ }^{d}$ Golden Agriculture Biotech Company Limited, No. 100 Xinzhou Road, Nanchang 330000, Jiangxi, China

(4)

(1)

6

* Corresponding author. State Key Laboratory of Food Science and Technology,

Nanchang University, Nanchang, Jiangxi 330047, China. Tel: +86 791

88305872(8106); Fax: +86 79188334509

1 E-mail address: liuchengmei@aliyun.com (C. Liu).

$2 * *$ Corresponding author. Department of Food Science, University of Massachusetts, 3 Amherst, MA 01003, USA. Tel.: +1 (413) 545 1019; fax: +1 (413) 5451262.

4 E-mail address: mcclements@foodsci.umass.edu (D.J. McClements).

${ }^{1}$ These authors contributed equally to this manuscript 
The influence of the degree of hydrolysis (DH) on the structure, solubility, rheology, and emulsifying properties of rice glutelin was investigated. Structural properties were characterized using analysis of molecular weight distribution, surface hydrophobicity, intrinsic fluorescence, and Circular Dichroism (CD) spectra. Protein hydrolysis changed molecular weight, increased flexibility, altered surface hydrophobicity, and increased solubility. Oil-in-water emulsions were prepared from rice glutelin with different $\mathrm{DH}(0.5 \%, 2 \%$, and $6 \%)$ and their stability to storage, $\mathrm{pH}$, salt, and thermal processing was assessed. The storage, $\mathrm{pH}$, salt, and temperature stability of the emulsions increased with decreasing hydrolysis. Emulsions prepared with $2 \%$ DH rice glutelin were stable over a range of environmental conditions: $\mathrm{pH} 7-9$; $\mathrm{NaCl}<100 \mathrm{mM}(\mathrm{pH} 7)$; temperatures $<90^{\circ} \mathrm{C}(\mathrm{pH} \mathrm{7,0} \mathrm{mM} \mathrm{NaCl})$ studied. These results

39 will facilitate the formulation and production of natural emulsion-based products using 40 rice glutelin as an emulsifier.

Keywords: rice glutelin; enzymatic hydrolysis; emulsion; stability; 


\section{Introduction}

The nature of the emulsifier used to formulate oil-in-water emulsions plays an important role in determining their structural, physicochemical and functional properties, such as droplet size, charge, interactions, stability, rheology, appearance, and digestibility (McClements, 2015). A wide variety of emulsifiers is available for utilization within the food industry, including synthetic surfactants, proteins, polysaccharides, and phospholipids (Kralova \& Sjoblom, 2009). Nevertheless, there is currently considerable interest in the utilization of natural emulsifiers in foods due to consumer demands for natural products and clean labels (Ozturk \& McClements, 2016). Many types of food proteins are amphiphilic molecules that can be used as emulsifiers to stabilize food emulsions (E. Dickinson, 2003; Eric Dickinson, 2011; Qian, Decker, Xiao, \& McClements, 2011; Qiu, Sun, Zhao, Cui, \& Zhao, 2013). The physicochemical and functional properties of emulsions depend on the interfacial characteristics of the protein molecules at the droplet surfaces, e.g., adsorption kinetics, surface load, packing, thickness, electrical charge, rheology, and hydrophobicity (E. Dickinson, 2003; Murray, 2002). At present, the majority of protein-based emulsifiers used in the food industry are derived from dairy sources e.g., whey proteins and caseins (Adjonu, Doran, Torley, \& Agboola, 2014; Ozturk et al., 2016; Wilde, 2009). However, there is interest in developing plant-based alternatives to these proteins due to allergenicity, economic, sustainability and dietary issues (Karaca, Low, \& Nickerson, 2015; Lam \& Nickerson, 2013; Ozturk et al., 2016).

In this study, we focused on the emulsifying properties of proteins derived from rice, a highly abundant staple food. Rice protein is rich in essential amino acids, has a high nutritive value, lowers cholesterol, and is hypoallergenic (Du et al., 2013; Qiang Zhao, Selomulya, et al., 2012). Previously, rice proteins have been reported to have good emulsifying properties under acidic conditions (Romero et al., 2012), but not under neutral conditions (Liu et al., 2011), which was attributed to differences in the aggregation state of the proteins under different $\mathrm{pH}$ conditions. The functional 
properties of proteins can often be improved by modification of their molecular structure and conformation using physical treatments (such as heating (Tang \& Ma, 2009) or sonication (L. Jiang et al., 2014)), chemical treatments (such as deamidation (Paraman, Hettiarachchy, \& Schaefer, 2007) or glycosylation (Du et al., 2013; Li et al., 2009)), or enzymatic treatments (Liu et al., 2011; Zheng et al., 2015). Moderate heating has been shown to significantly enhance the functional properties of vicilin-rich protein isolates (such as solubility, emulsifying activity, and foaming activity), while excessive heating has been shown to reduce these properties (Tang et al., 2009). Enzymatic treatments are often preferred for this purpose due to the mild reaction conditions required, and the high degree of specificity in altering molecular properties (Guan, Yao, Chen, Shan, \& Zhang, 2007). In the current study, we focused on using hydrolytic enzymes to alter the degree of hydrolysis $(\mathrm{DH})$ of rice glutelin so as to improve its solubility and emulsifying properties.

A number of previous studies have examined the factors that influence the emulsifying properties of rice protein hydrolysates. Studies have shown that combining rice protein hydrolysates $(\mathrm{DH}=7.8 \%)$ with a non-ionic surfactant (Tween 20) can lead to the formation of more stable emulsions than possible with the protein hydrolysates alone (Qiang Zhao, Xiong, et al., 2012). Moreover, these combined rice protein hydrolysates/Tween 20 systems have been shown to have good antioxidant activity in emulsions (Cheetangdee \& Benjakul, 2015). However, the utilization of a synthetic surfactant to improve the functional attributes of rice protein hydrolysates is undesirable for products that required an all-natural label. Some studies have shown that rice protein hydrolysates can adsorb to oil droplet surfaces but that they are not very effective in preventing coalescence, which may be because the interfacial layers formed are relatively thin and mobile (Adjonu et al., 2014; Lam et al., 2013). In general, emulsion stability depends on the effectiveness of the emulsifier at producing small droplets during homogenization, and then preventing their aggregation during storage or when environmental conditions are changed (McClements, 2015; Qian et al., 2011). 
The ability of rice glutelin to form and stabilize emulsions is likely to depend on

107 the degree of hydrolysis, since this will affect the molecular and functional

108 characteristics of the hydrolyzed proteins. We therefore compared the influence of

109 different degrees of hydrolysis on the molecular weight distribution, conformation,

110 surface hydrophobicity, and functionality (solubility, rheology, and emulsifying

111 properties) of rice glutelin. In addition, the impact of different environmental

112 conditions ( $\mathrm{pH}$, ionic strength, and temperature) on the stability of the emulsions

113 formed was examined so as to elucidate conditions where the proteins could be

114 effectively used as ingredients in foods. This study is important for the identification of

115 natural hypoallergenic protein emulsifiers that can be used in the development of

116 label-friendly emulsion systems.

117 2. Materials and Methods

\subsection{Materials}

119 Rice protein (90.3 wt\%, dry basis) was kindly provided by Golden Agriculture

120 Biotech Company Limited (Jiangxi, China). Sodium chloride, sodium azide, trypsin,

121 and other chemicals were of analytical grade and were obtained from Sigma-Aldrich

122 (Sigma Chemical Co., St. Louis, MO).. Double-distilled water was used throughout to 123 prepare all solutions and emulsions.

\subsection{Extraction of rice glutelin}

Rice glutelin was extracted from rice protein based on its differential solubility in

126 different solutes using a procedure described previously (Ju, Hettiarachchy, \& Rath,

127 2001; Likitwattanasade \& Hongsprabhas, 2010). Rice protein was washed with 5\%

$128 \mathrm{NaCl}$ solution, $70 \%$ ethanol and distilled water until no protein was detected in the

129 washing liquor. The final glutelin was recovered by centrifugation at $3000 \mathrm{~g}$ for $30 \mathrm{~min}$,

130 freeze-dried, and stored at $-20^{\circ} \mathrm{C}$. The protein content of rice glutelin was $93.42 \%$ (dry

131 basis) as determined by the Kjeldahl method $(\mathrm{N} \%$ × 5.95) (Qiang Zhao, Selomulya, et

132 al., 2012). 


$$
\alpha=\frac{10^{p H-p K_{a}}}{1+10^{p H-p K_{a}}}
$$

154 Here $\mathrm{pH}$ is the value at which the enzyme hydrolysis was conducted, and $\mathrm{pK}_{\mathrm{a}}$ is the 155

\subsection{Preparation of rice glutelin hydrolysates}

Rice glutelin was hydrolyzed by trypsin at an optimized enzyme/substrate ratio according to preliminary experiments. $2 \mathrm{~g}$ of rice glutelin was dispersed in $30 \mathrm{~mL}$ deionized water and stirred for $1 \mathrm{~h}$. After $\mathrm{pH}$ and temperature adjustments $(\mathrm{pH}=8,50$ ${ }^{\circ} \mathrm{C}$ ), Trypsin was added. Inactivation of the enzyme was achieved by heating to $95^{\circ} \mathrm{C}$ for $10 \mathrm{~min}$ followed by immediate cooling in water to room temperature. The mixture was adjusted to $\mathrm{pH}$ 7.0, followed by centrifugation (TGL-20B, Anting Scientific Instrument Factory, Shanghai, China) at $4800 \mathrm{~g}$ for $10 \mathrm{~min}$ and the supernatant was freeze-dried. The hydrolysates formed had $0.5 \%, 2 \%$ and $6 \% \mathrm{DH}$, and were therefore referred to as DH0.5RG, DH2RG and DH6RG, respectively.

\subsection{Estimation of the degree of hydrolysis}

The degree of hydrolysis (DH), defined as the number of hydrolyzed peptide bonds (h) relative to the number of peptide bonds per unit weight $\left(\mathrm{h}_{\mathrm{tot}}\right)$ expressed as a percentage, was determined by using the $\mathrm{pH}$-stat method (Adler-Nissen, 1986) and calculated according to the following equation:

$$
\mathrm{DH}=\frac{h}{h_{t o t}} \times 100 \%=\frac{\mathrm{BN}_{\mathrm{b}}}{\alpha h_{t o t} \mathrm{M}_{p}} \times 100 \%
$$

Where $B$ is base consumption (mL), $\mathrm{N}_{\mathrm{b}}$ is the molarity of the base used, $\mathrm{M}_{p}$ is the mass $(\mathrm{g})$ of the protein, $\mathrm{h}_{\text {tot }}$ is the theoretical overall number of peptide bonds in the protein substrate (7.40 meq/g rice protein) (Qiang Zhao, Xiong, et al., 2012), and $\alpha$ is the average degree of dissociation of the $\alpha-\mathrm{NH}_{2}$ groups expressed as: average $\mathrm{pK}_{\mathrm{a}}$ for $\alpha-\mathrm{NH}_{3}{ }^{+}$groups on the protein. The value of $\alpha$ was 0.885 at $\mathrm{pH} 8$ and 50 ${ }^{\circ} \mathrm{C}$ treatment (Adler-Nissen, 1986; García-Moreno et al., 2014). 


\subsection{Structural characteristics of hydrolyzed rice glutelin}

158

159

160

161

162

163

164

165

166

167

168

169

170

171

172

173

174

175

176

177

178

179

180

181

182

183

184

\subsubsection{Molecular weight distribution}

A high performance size exclusion chromatography (SEC-HPLC) system (Agilent 1260 series) equipped with an appropriate column (Shodex KW804) was used according to the methods described previously (Liu et al., 2011) with some modification. Protein samples were dissolved in $100 \mathrm{mM}$ phosphate buffer $(\mathrm{pH} 7.0)$ containing $20 \mathrm{mg} / \mathrm{mL}$ SDS. The supernatants were collected after centrifuged at $4800 \mathrm{~g}$ for $10 \mathrm{~min}$. All protein solutions were filtered through $0.45 \mu \mathrm{m}$ cellulose acetate membranes (Millipore, Billerica, MA) before use. The eluent used was $200 \mathrm{mM}$ phosphate buffer $(20 \mathrm{mg} / \mathrm{mL}$ SDS, $\mathrm{pH} 7.0)$ at a flow rate of $1 \mathrm{~mL} / \mathrm{min}$ used at room temperature. The UV absorbance at $220 \mathrm{~nm}$ was performed to monitor protein elution.

\subsubsection{Sodium dodecyl sulfide polyacrylamide gel electrophoresis (SDS-PAGE)}

SDS-PAGE of protein samples was performed according to a method described previously (Laemmli, 1970) by using 12\% separating gel and 5\% stacking gel. Protein samples were mixed with the sample buffer: $0.5 \mathrm{M}$ Tris- $\mathrm{HCl}, 10 \%$ glycerol, with or without $5 \% \beta$-mercaptoethanol ( $\beta$-ME), and $1 \%(\mathrm{w} / \mathrm{v})$ bromophenol blue $(\mathrm{pH} 6.8)$. The mixtures were heated at $100{ }^{\circ} \mathrm{C}$ for $10 \mathrm{~min}$, and then centrifuged at $10,000 \mathrm{rpm}$ for $30 \mathrm{~s}$. A sample containing $40 \mu \mathrm{g}$ of protein was loaded into each well, and subjected to electrophoresis at a voltage of $60 \mathrm{~V}$ in the stacking gel and $80 \mathrm{~V}$ in the separating gel until the tracking dye reached the bottom of the gel. Then the gels were stained for $2 \mathrm{~h}$ using 0.05\% Coomassie Brilliant Blue R-250 in acetic acid/methanol/water solution (46:227:227, v/v/v) and destained for $6 \mathrm{~h}$ with methanol/acetic acid/water solution $(50: 75: 875, \mathrm{v} / \mathrm{v} / \mathrm{v})$.

\subsubsection{Surface hydrophobicity}

The surface hydrophobicity $\left(\mathrm{H}_{0}\right)$ of the proteins was determined as reported previously (Zheng et al., 2015) using 1-anilino-8-naphthalene sulphonate (ANS) as a hydrophobic fluorescence probe. Protein solutions were diluted with $10 \mathrm{mM}$ sodium phosphate buffer $(\mathrm{pH}=7.0)$ to give concentrations ranging from $0.01 \mathrm{mg} / \mathrm{mL}$ to 0.1 
$\mathrm{mg} / \mathrm{mL} .20 \mu \mathrm{L}$ of ANS solution $(8 \mathrm{mM})$ was added to $2 \mathrm{~mL}$ of sample solution and incubated in the dark for $20 \mathrm{~min}$ at ambient temperature. An ANS blank was also prepared, which consisted of $2 \mathrm{ml}$ buffer and $20 \mu \mathrm{L}$ of the ANS probe. The fluorescence intensity was measured using the excitation and emission wavelengths of 390 and 470 $\mathrm{nm}$, respectively. The excitation and emission slits used were both $2.5 \mathrm{~nm}$. The initial slope of the relative fluorescent intensity vs. sample concentration $(\mathrm{mg} / \mathrm{mL})$ plots was evaluated by linear regression analysis and used as an index of $\mathrm{H}_{0}$. Each spectrum was corrected with respect to the corresponding blank.

\subsubsection{Intrinsic fluorescence}

The fluorescence emission spectrum of samples was performed using a fluorescence spectrofluorimeter (F-7000, Hitachi, Tokyo, Japan) according to a method described previously (Avramenko, Low, \& Nickerson, 2013) with a slight modification. $0.01 \mathrm{mg} / \mathrm{mL}$ of protein samples were prepared using $10 \mathrm{mM}$ phosphate buffer $(\mathrm{pH} 7)$. The intrinsic fluorescence spectra were then obtained using an excitation wavelength of $280 \mathrm{~nm}$ and acquiring emission spectra between 300 and $500 \mathrm{~nm}$. The excitation and emission slit were both adjusted to $2.5 \mathrm{~nm}$ during these measurements. The fluorescent intensity (FI) was reported as a function of emission wavelength. All fluorescence experiments were performed in triplicate.

\subsubsection{Circular dichroism studies}

The far-UV CD spectra were determined on a Bio-Logic MOS-450 CD spectrometer (French Bio-Logic SAS, Claix, French) according to a method described previously (Du et al., 2013) using a $1.0 \mathrm{~mm}$ path length quartz cuvette. $0.1 \mathrm{mg} / \mathrm{mL}$ of protein solutions were prepared by dissolving samples in $10 \mathrm{mM}$ phosphate buffer $(\mathrm{pH}$ 7.0). All the samples were scanned from 190 to $250 \mathrm{~nm}$ and the spectrum of the protein-free buffer was extracted from that of the sample. The analysis of the CD spectroscopic data was carried out using the online SELCON3 method in

\section{DICHROWEB.}




\subsection{Protein solubility}

213 Protein solubility was analyzed using the Lowry method (Lowry, Rosebrough, Farr,

$214 \&$ Randall, 1951) with bovine serum albumin as standard. An aqueous solution (1\%,

$215 \mathrm{w} / \mathrm{v}$ ) of protein sample was stirred magnetically at $25^{\circ} \mathrm{C}$ for $30 \mathrm{~min}$, and then the $\mathrm{pH}$

216 was adjusted to 3 to 10 using either $0.5 \mathrm{M} \mathrm{HCl}$ or $0.5 \mathrm{M} \mathrm{NaOH}$. After $30 \mathrm{~min}$ of stirring,

217 the $\mathrm{pH}$ was readjusted if necessary. The dispersions were centrifuged at $4800 \mathrm{~g}$ for 15

$218 \mathrm{~min}$, and the protein content of the supernatant was analyzed. Protein solubility was

219 expressed as the amount of protein in the supernatant relative to the total protein

220 content in the dispersion. All measurements were conducted in triplicate.

\subsection{Emulsion preparation}

An emulsifier solution was prepared according to a method described earlier (Qiu, Zhao, \& McClements, 2015) with some slight modifications. The protein samples were dispersed into $10 \mathrm{mM}$ phosphate buffer ( $\mathrm{pH} \mathrm{7.0)}$ ) and stirred for $3 \mathrm{~h}$ to ensure complete hydration. Then the solution was centrifuged at $4000 \mathrm{~g}$ for $15 \mathrm{~min}$ and the final supernatant was collected. A coarse emulsion was prepared by pre-homogenizing 10 $\mathrm{mL}$ of corn oil with $90 \mathrm{~mL}$ of emulsifier solution $(5 \mathrm{mg} / \mathrm{mL})$ using a high-shear mixer (M133/1281-0, Biospec Products Inc., ESGC, Switzerland) at $12000 \mathrm{rpm}$ for $2 \mathrm{~min}$, and then emulsified using a Microfluidizer (NCJJ-0.007/200, Langfang Tongyong Machinery Manufacturing Co., Ltd, China) for 3 times at $80 \mathrm{MPa} .0 .01 \%$ (w/w) of sodium azide was then added to the emulsions to prevent microbial growth.

\subsection{Emulsion charaterization}

\subsubsection{Flow behaviour measurements}

The rheological properties of the samples were characterized according to the methods described previously (Qiangzhong Zhao et al., 2015) using a dynamic shear rheometer (Paar Physica rheometer, MCR 302, Anton Paar GmbH, Germany) with a parallel-plate geometry (20 mm diameter and $1 \mathrm{~mm}$ gap) at $25^{\circ} \mathrm{C}$. The extra sample around the edge of the plates was trimmed off, and a thin layer of mineral oil was applied to prevent moisture loss of the samples during measurements. The shear stress 
240 was then measured as the shear rate was increased from 5 to $100 \mathrm{~s}^{-1}$. The power law

241 model was used to calculate the flow behaviour index and consistency coefficient of the 242 samples:

$243 \tau=\mathrm{K} \gamma^{\mathrm{n}}$

244 Here, $\tau$ is the shear stress $(\mathrm{mPa})$; $\mathrm{K}$ is the consistency coefficient $\left(\mathrm{mPa} \mathrm{s}^{\mathrm{n}}\right) ; \gamma$ is the shear 245 rate $\left(\mathrm{s}^{-1}\right)$; and $\mathrm{n}$ is the flow behaviour index.

\subsubsection{Particle size and surface charge $(\zeta$-potential) measurement}

The particle size and $\zeta$-potential of the emulsions were measured by dynamic light scattering (Nicomp ${ }^{\mathrm{TM}} 380$ ZLS, PSS Nicomp, Santa Barbara, CA, USA). Prior to measurement, the emulsions were diluted 100-fold with the working buffer to avoid

250 multiple scattering during measurements. Duplicate measurements were performed at $25125^{\circ} \mathrm{C}$ on each sample.

\subsubsection{Influence of environmental stress on emulsion stability}

The emulsions were exposed to a number of environmental stresses to simulate the conditions that they may experience during their application in commercial products:

\subsubsection{Influence of $p H$}

Freshly produced emulsions were placed into $50 \mathrm{~mL}$ beakers and each sample was adjusted to different $\mathrm{pH}$ values (3-9) by adding either $\mathrm{HCl}$ or $\mathrm{NaOH}$ solutions. The samples were then transferred to $10 \mathrm{~mL}$ test tubes and stored at $25^{\circ} \mathrm{C}$ for $24 \mathrm{~h}$ prior to particle size and $\zeta$-potential analysis.

\subsubsection{Influence of $\mathrm{NaCl}$}

Freshly prepared emulsions were transferred into $10 \mathrm{~mL}$ test tubes, and then varying ratios of $6 \mathrm{M} \mathrm{NaCl}$ solution and buffer solution were added to obtain samples with various final $\mathrm{NaCl}$ concentrations $(0-300 \mathrm{mM})$. The samples were vortexed and stored for $24 \mathrm{~h}$ at $25^{\circ} \mathrm{C}$ prior to particle size and $\zeta$-potential determination.

\subsubsection{Influence of temperature}

Freshly prepared emulsions were transferred into $10 \mathrm{~mL}$ test tubes, which were 
then were placed into a water bath set at different temperatures $\left(30-90^{\circ} \mathrm{C}\right)$ for $30 \mathrm{~min}$ and cooled to ambient temperature immediately. The samples were vortexed and stored

269 for $24 \mathrm{~h}$ at $25^{\circ} \mathrm{C}$ prior to particle size and $\zeta$-potential determination, and for 15 days 270 prior to visual observation of creaming stability.

\subsection{Statistical analyses}

All the experiments were conducted in triplicate and the data are expressed as means values \pm standard deviation (SD). Significant differences between means $(\mathrm{p}<0.05)$ were studied by one-way ANOVA test using SPASS 19.0 (SPSS Inc., Chicago, 275 IL).

\section{Results and discussion}

\subsection{Molecular weight distribution of glutelin hydrolysates}

Size exclusion chromatography was used to determine the molecular weight

279 distribution of the native rice glutelin (RG) and the rice glutelin hydrolysates (RGH)

280 (Fig.1). The RG chromatogram was characterized by two major peaks with a molecular 281 weight $>678 \mathrm{kDa}(\mathrm{P} 1)$ and $44 \mathrm{kDa}(\mathrm{P} 2)$. The $\mathrm{P} 1$ peak has previously been attributed to

282 large macromolecular complexes polymerized by disulfide bonds (Liu et al., 2011;

283 Utsumi, 1992). The P2 peak was most likely to be the $\alpha$-subunit and $\beta$-subunit of RG.

284 Upon hydrolysis, the area of the P1 peak significantly decreased, suggesting that RG

285 was hydrolyzed by trypsin. The P1 peak was actually larger for the RG with DH 6\%

286 than with DH $0.5 \%$ and $2 \%$, which suggests the formation of soluble peptide aggregates

287 at high degrees of hydrolysis. Hydrolysis-induced aggregation of glutelin was also 288 reported previously (Barac et al., 2012), indicating that protein aggregates could be 289 produced during hydrolysis or during thermal inactivation of the enzyme. Furthermore, 290 after hydrolysis the P2 peak disappeared, whereas two new peaks (P3 and P4) appeared. 291 This suggested that RG was hydrolyzed into small peptides.

\subsection{SDS-PAGE analysis}

293 The polypeptide profiles of protein samples were measured under reducing and 
non-reducing conditions to investigate changes of RG composition (Fig. 2). Under non-reducing conditions, the RG sample showed three major subunits (around 30, 20 and $12 \mathrm{kDa}$ ) (Fig.2a). The 30 and $20 \mathrm{kDa}$ subunits correspond to the acidic $\alpha$-subunit and alkaline $\beta$-subunit of $\mathrm{RG}$, respectively. The $12 \mathrm{kDa}$ fraction corresponds to

298 prolamin, which is known to be an integral part of RG (Likitwattanasade et al., 2010; 299 Shabbir, Anjum, Zahoor, \& Nawaz, 2011; Zarins \& Chrastil, 1992). Furthermore, high molecular weight (> $260 \mathrm{kDa}$ ) aggregates of $\mathrm{RG}$ were also observed at the top of the

301 stacking and separating gels. Upon hydrolysis, the bands at $20 \mathrm{kDa}$ and $30 \mathrm{kDa}$ disappeared accompanied by appearance of new subunits $<14 \mathrm{kDa}$. These results support the conclusion that the protein structure changed upon treatment with trypsin (Avramenko et al., 2013). An increase of DH induced a shift of the RG band towards lower molecular weight regions. DH0.5 RG had major fractions with molecular weights $<15 \mathrm{kDa}$ while DH6 RG had more fractions with molecular weights $<12 \mathrm{kDa}$. Our results match with previous studies (Avramenko et al., 2013), that reported that smaller lentil protein isolate sub-units were produced upon treatment with trypsin under non-reducing conditions, while few differences in SDS-PAGE profiles were observed

310 for hydrolyzed samples.

311 The SDS-PAGE profiles measured under reducing conditions (Fig. 2b) were fairly 312 similar to those measured under non-reducing conditions (Fig. 2a). However, some of 313 the larger molecular weight fractions were not observed under reducing conditions, 314 which suggested that some of the larger protein aggregates were disrupted in the 315 presence of $\beta$-ME. These results suggest that these large aggregates were held together 316 by disulfide bonds in both the native and hydrolyzed rice glutelin.

\subsection{Surface hydrophobicity $\left(\mathbf{H}_{0}\right)$}

318 It is widely recognized that the surface hydrophobicity of proteins plays an 319 important role in determining their conformation and functional properties ( $\mathrm{S}$.

320 Damodaran, Parkin, \& Fennema, 2007). The $\mathrm{H}_{0}$ values of RG and RGH with different 321 DH were therefore quantified (Fig. 3a). The $\mathrm{H}_{0}$ value of the hydrolysates initially 322 increased with increasing hydrolysis ( 0 to $2 \% \mathrm{DH})$, but then it decreased at the highest 
323 DH value $(6 \% \mathrm{DH})$. The increase in $\mathrm{H}_{0}$ can be attributed to the fact that limited

324 hydrolysis of protein was accompanied by partial unfolding of the protein structure and 325 exposure of hydrophobic sites previous buried within the interior of the protein 326 (Avramenko et al., 2013; Jung, Murphy, \& Johnson, 2005). An increase in $\mathrm{H}_{0}$ of 327 proteins due to partial hydrolysis with trypsin has been reported previously (Guan et al., 328 2007), as has a decrease in $\mathrm{H}_{0}$ upon further hydrolysis (Jung et al., 2005). According 329 to previous studies (Avramenko et al., 2013; Jung et al., 2005), the decrease in 330 hydrophobicity could be due to (1) enzymatic hydrolysis breakdowns hydrophobic 331 areas that may be contribute to surface hydrophobicity; (2) reducing the surface area of 332 the hydrophobic groups exposed to the surrounding water by protein-protein 333 aggregation. In summary, the $\mathrm{RGH}$ with a $\mathrm{DH}$ of $2 \%$ had the highest $\mathrm{H}_{0}$ value.

\subsection{Intrinsic fluorescence}

Fluorescence intensity measurements provide an indication on the extent of exposure of aromatic amino acids to water, which is related to changes of protein tertiary conformation (Cui, Zhao, Yuan, Zhang, \& Ren, 2013; Roger, 2004). The emission fluorescence spectroscopic for $\mathrm{RG}$ and $\mathrm{RGH}$ as a function of $\mathrm{DH}$ were therefore measured (Fig. 3b). The fluorescence intensities of RGH were found to be higher than that of RG, which can be attributed to the fact that more of the aromatic groups were exposed to water and more available to emit fluorescence (Roger, 2004; Sponton, Perez, Carrara, \& Santiago, 2014). In agreement with the surface hydrophobicity measurements, the fluorescent intensity of the hydrolysates with $6 \%$ DH was lower than that with $2 \% \mathrm{DH}$, which suggests that less aromatic groups were exposed to water. This effect can again be attributed to hydrophobic attraction of the polypeptides and peptides at high degrees of hydrolysis, since the hydrophobic groups were re-buried within the interior of larger aggregates (Avramenko et al., 2013). A similar result has been reported for peanut protein isolate treated with alcalase (G. Zhao, Liu, Zhao, Ren, \& Yang, 2011). 


\subsection{CD spectra analysis}

A deeper understanding of RG and RGH secondary structure was obtained using CD spectra (Table 1). Compared with the native RG, the $\beta$-sheet regions in the RGH decreased from $30.9 \%$ to $21.1 \%$ by hydrolysis with $\mathrm{DH}$ of $6 \%$, whereas the contents of random coil and $\alpha$-helix regions increased from $29.7 \%$ to $38.6 \%$ and from $17.7 \%$ to $22.8 \%$, respectively. It has been reported that the $\beta$-sheet structures ("trains") are relatively stable, whereas the $\alpha$-helix, $\beta$-turn, and random coil structures ("loops") are relatively flexible and open (Srinivasan Damodaran, 2007; Yong, Yamaguchi, \& Matsumura, 2006). This would suggest that enzyme hydrolysis led to a more extended form of the RG secondary structure, which was in agreement with the results of the intrinsic fluorescence measurements. According to previous studies (Yong et al., 2006), the secondary structure in wheat gluten becomes more flexible form after treatment with protein-glutaminase, with decreasing $\beta$-sheet regions and increasing $\alpha$-helix, $\beta$-turn and random coil regions. Proteins with more flexible structures adsorb more easily to oil-water interfaces, and may therefore be better emulsifiers (Z. Jiang et al., 2015).

\subsection{Protein solubility}

Good water-solubility of proteins is often a prerequisite for their proper functioning as emulsifiers, and so we measured the influence of $\mathrm{pH}$ on the water solubility of the native protein and hydrolysates (Fig. 3c). The solubility of all samples exhibited U-shape curves, with minimal values around $\mathrm{pH} 5$ for RG (2.2\%) and around $\mathrm{pH} 4$ for the hydrolysates (60-71\%). Overall, the solubility of the hydrolysates was much higher than the native proteins, and the solubility increasing with increasing $\mathrm{DH}$. The lower solubility at intermediate $\mathrm{pH}$ values can be attributed to the reduction in the electrostatic repulsion between the proteins around their isoelectric point (Du et al., 2012). The shift in the isoelectric point after partial hydrolysis has also been reported in earlier studies, and may be attributed to differences in the types and numbers of charged groups on the proteins after hydrolysis (Jamdar et al., 2010; Ochiai, Kamata, \& Shibasaki, 1982). The poor solubility of RG may due to 
the large rigid macromolecule structure, with subunits linked by multiple intermolecular and intramolecular disulfide bonds and hydrophobic interactions (Paraman et al., 2007). The disulfide bond content of glutelin has been reported to decrease after hydrolysis, which may lead to a decrease in protein aggregation and improvement in protein solubility (Zheng et al., 2015). The solubility of RGH was significantly higher than that of $\mathrm{RG}$ at all $\mathrm{pH}$ values $(p<0.05)$. Partial hydrolysis of other types of glutelin has also been reported to increase water-solubility, such as corn glutelin (Zheng et al., 2015) and barely glutelin (Xia, Bamdad, Gänzle, \& Chen, 2012). Partial hydrolysis of hemp protein isolate has also been reported to improve its water-solubility (Yin et al., 2008). The improved solubility of RGH can be attributed to the reduction of molecular weight, the unfolding of the peptide chains, and the release of soluble aggregates from insoluble aggregates or precipitates (Ghribi et al., 2015; Zheng et al., 2015).

\subsection{Emulsion stability}

In this section, the influence of various environmental stresses on the physical state of oil-in-water emulsions was studied. Preliminary experiments showed that RG could not form stable emulsions. Instead, these systems rapidly separated into separate oil and aqueous phases, which suggested that the water-insoluble RG was unsuitable as an emulsifier. Consequently, only the three RGH $(0.5,2$, and 6\% DH) were used for the emulsion stability studies.

\subsubsection{Storage stability}

Changes in the size of the droplets in the emulsions were measured throughout 7 days of storage at ambient temperature (Fig. 4). The initial mean diameter of the droplets formed after homogenization increased with increasing hydrolysis: $0.5 \% \mathrm{DH}$ $(221 \mathrm{~nm})<2 \% \mathrm{DH}(233 \mathrm{~nm})<6 \% \mathrm{DH}(253 \mathrm{~nm})$. This suggests that the protein hydrolysates with a lower DH were able to adsorb to the droplet surfaces more rapidly during homogenization, or that they were more effective at preventing recoalescence inside the homogenizer (Hakansson, Tragardh, \& Bergenstahl, 2009). During storage 
there were distinct differences between the ability of the hydrolysates to prevent particle growth. There was a slight increase in mean particle diameter over time for the $0.5 \% \mathrm{DH}$ samples, little change for the $2 \% \mathrm{DH}$ samples, and a relatively rapid increase for the 6\% DH samples (Fig. 4). This result suggests that there was an optimum degree of hydrolysis required to prevent droplet aggregation during storage. A similar finding was reported for hydrolysates formed from whey proteins (Euston, Finnigan, \& Hirst, 2001). It should be noted that the most likely origin for the measured increase in particle size over time was due to flocculation, as there was a corresponding increase in the viscosity of the samples (Section 3.7).

\subsection{2 pH}

The influence of $\mathrm{pH}$ on the mean particle diameter and $\zeta$-potential of the different emulsions was measured (Fig. 5). All the emulsions exhibited fairly similar trends in the particle size versus $\mathrm{pH}$ profiles: extensive droplet aggregation occurred from $\mathrm{pH} 3$ to 5, but the emulsions were stable from pH 7 to 9 (Fig. 5a). Visual observation of the samples also showed that the emulsions separated into a transparent serum layer at the top and a white cream layer at the bottom from $\mathrm{pH} 3$ to 5, but were stable to creaming at pH 7 to 9 (data not shown). The creaming instability at lower $\mathrm{pH}$ values can be attributed to the fact that the creaming velocity increases with particle size (McClements, 2015). These results are consistent with previous studies that have reported that $\mathrm{RG}$ emulsions are highly unstable to aggregation and creaming near the proteins isoelectric point (Du et al., 2013).

To provide some further insights into the mechanism of emulsion instability, the electrical characteristics of the protein-coated droplets were measured at different $\mathrm{pH}$ values (Fig. 5b). For all the emulsions, the $\zeta$-potential went from highly positive at low $\mathrm{pH}$ to highly negative at high $\mathrm{pH}$, with a zero change at around $\mathrm{pH} 4.3$. This finding can be attributed to the fact that the isoelectric point of the adsorbed layer of RG hydrolysates was around $\mathrm{pH} 4.3$, which was in agreement with the solubility results. At low $\mathrm{pH}$ values, the $\mathrm{H}^{+}$concentration is relatively high, which causes the carboxyl groups $(-\mathrm{COOH})$ and amino groups $\left(-\mathrm{NH}_{3}{ }^{+}\right)$to become protonated leading to a net 
positive charge. Conversely, at high $\mathrm{pH}$ values, the $\mathrm{H}^{+}$concentration is relatively low,

437 which causes the carboxyl groups $\left(-\mathrm{COO}^{-}\right)$and amino groups $\left(-\mathrm{NH}_{2}\right)$ to be

438 non-protonated leading to a net negative charge. At the isoelectric point, the number of

439 positive and negative groups is balanced. The interfacial layers formed by globular

440 proteins are known to be relatively thin, and so the major type of interactions

441 preventing droplet aggregation is electrostatic repulsion (Qian et al., 2011). Thus, the

442 reduction in the net droplet charge at $\mathrm{pH}$ values around the isoelectric may have

443 promoted droplet flocculation since then the electrostatic repulsion was not large

444 enough to overcome the van der Waals attraction (Ozturk, Argin, Ozilgen, \&

445 McClements, 2015).

$446 \quad$ 3.7.3 Ionic strength

447 The influence of ionic strength on particle size and $\zeta$-potential of the different 448 emulsions ( $\mathrm{pH} 7$, ambient temperature) was measured (Fig. 6). All the emulsions were 449 destabilized by addition of $\mathrm{NaCl}$, as seen by an increase in the mean particle diameter. 450 Droplet aggregation can be attributed to the ability of the counter ions $\left(\mathrm{Na}^{+}\right)$in the salt 451 to screen the electrostatic repulsion between the negatively charged droplets (Salminen $452 \&$ Weiss, 2014). When the $\mathrm{NaCl}$ concentration was above a critical level, the 453 electrostatic repulsion could no longer overcome the attractive interactions (van der 454 Waals and hydrophobic) between the droplets, thereby leading to aggregation. The oil 455 droplets coated by the $2 \%$ DH rice glutelin showed the least change in particle size with 456 increasing salt content in the range 0 to $100 \mathrm{mM} \mathrm{NaCl}$.

457 The addition of $\mathrm{NaCl}$ led to a slight reduction in the magnitude of the negative 458 charge on the droplets (Fig. 6b), which can again be attributed to electrostatic screening 459 effects (Israelachvili, 2011).

\subsubsection{Temperature}

461 The effect of temperature on the mean particle diameter, $\zeta$-potential, and creaming 462 stability of the emulsions ( $\mathrm{pH} \mathrm{7,0} \mathrm{mM} \mathrm{NaCl}$ ) was measured (Fig. 7). The emulsions 463 containing oil droplets coated by rice glutelin with a low level of hydrolysis ( 0.5 and $2 \%$ 
$464 \mathrm{DH})$ were relatively stable to thermal processing, with little change in mean particle 465 diameter from 30 to $90^{\circ} \mathrm{C}$ (Fig. 7a). Conversely, there was an appreciable increase 466 the particle size of the emulsions stabilized by the $6 \% \mathrm{DH}$ rice glutelin upon heating. 467 The increase in droplet aggregation in this sample may have occurred because of a 468 decrease in the electrostatic repulsion between the droplets (Zhang, Wu, Yang, He, \& 469 Wang, 2012), or due to an increase in the exposure of hydrophobic groups during 470 heating leading to an increase in electrostatic attraction and/or formation of disulfide 471 bonds (Charoen et al., 2011). The $\zeta$-potential measurements support the notion that 472 there was an alteration in the interfacial composition or structure at the droplet 473 for the 6\% RH samples (Fig. 7b). In these emulsions there was an appreciable 474 in the $\zeta$-potential of protein-coated droplets upon heating, but there was little change 475 the other samples. The reduction in the magnitude of the electrical charge on the $6 \%$ 476 DH samples could have led to a reduction in electrostatic repulsion between the 477 droplets, thereby promoting droplet flocculation. This change in electrical charge 478 have occurred because of a change in interfacial properties due to rearrangement or desorption of the peptide molecules at the droplet surfaces. These processes could

480 have also led to an increase in surface hydrophobicity, which could also promote 481 flocculation. A higher degree of hydrolysis may have led to smaller peptides that were 482 more easily desorbed from the droplet surfaces. Interestingly, RGH with the lowest 483 degree of hydrolysis $(0.5$ and $2 \% \mathrm{DH})$ did not show an appreciable change in $484 \zeta$-potential or stability upon heating. Consequently, these hydrolysates may be more suitable for applications where thermal stability is required.

486 Visual observation of the emulsions supported the particle size measurements. 487 The emulsions containing RGH with low levels of hydrolysis $(0.5$ and $2 \% \mathrm{DH})$ were 488 relatively stable to creaming, whereas those with high levels of hydrolysis (6\%) 489 exhibited distinct phase separation (Fig. 7c). Indeed, heating caused these emulsions 490 to form a watery layer at the bottom and a curd-like cream layer at the top.

492 The rheology of food emulsions is important in many practical applications, and 
so the viscosity-shear rate profiles of the emulsions were measured using a shear rheometer during storage at ambient temperature for 7 days $(\mathrm{pH} 7,0 \mathrm{mM} \mathrm{NaCl})$. The resulting flow curves were then fitted to the power law model, and the consistency coefficient (K) and flow behaviour index (n) were calculated (Table 2). The flow behaviour index (n) is 1 for a Newtonian fluid and less than 1 for a shearing thinning fluid. Initially, all the emulsions had a relatively low consistency coefficient and exhibited weak shearing thinning behaviour. After 7 days of storage, there was little change in the $\mathrm{K}$ and $\mathrm{n}$ values of the emulsions stabilized by the $2 \% \mathrm{DH}$ rice glutelin, suggesting that it was stable to droplet aggregation, which is in agreement with the particle size measurements for this sample (Fig. 4). Conversely, there was an appreciable increase in the consistency index of the other two emulsions, and shear-thinning behaviour was observed. The phenomenon is indicative of extensive droplet flocculation in the emulsions (Qiu, Zhao, Decker, \& McClements, 2015; Taherian, Britten, Sabik, \& Fustier, 2011; Tang \& Liu, 2013), and is again consistent with the observed increase in particle size in these emulsions during storage (Fig. 4).

\section{Conclusions}

This study demonstrates that the stability of emulsions prepared using rice glutelin hydrolysates as emulsifiers depends on the degree of hydrolysis of the protein molecules. Hydrolysis of glutelin made the protein structure more flexible, and transformed the insoluble aggregates present in the native protein to soluble aggregates in the hydrolyzed protein. The surface hydrophobicity and intrinsic fluorescence of the hydrolysates first increased and then decreased as the degree of hydrolysis increased, which was attributed to exposure of buried hydrophobic groups to the outer surface of the molecule followed by protein aggregation through hydrophobic interaction. The rice glutelin hydrolysates were found to have much higher solubility than that of the original glutelin across the entire $\mathrm{pH}$ range studied. However, oil droplets stabilized by the rice glutelin hydrolysates were highly unstable to aggregation at $\mathrm{pH}$ values around the isoelectric point of the adsorbed proteins, and 
521 upon addition of salt. These results highlighted the importance of electrostatic

522 interactions in stabilizing the protein-coated droplets against aggregation. The rice

523 glutelin with 2\% DH gave emulsions that had the best storage stability and that were

524 most resistant to salt addition and thermal processing. Overall, these results suggest

525 that hydrolysis of native rice glutelin can be used to improve its functional properties

526 so that it can be used as an effective emulsifier. However, further research is needed

527 to improve the stability of the emulsions over a wide range of environmental

528 conditions.

\section{Acknowledgements}

530 This study was supported by the Freedom Explore Program of State Key

531 Laboratory of Food Science and Technology of Nanchang University (No.

532 SKLF-ZZB-201512), and Goal-oriented Subjects of State Key Laboratory of Food

533 Science and Technology of Nanchang University (SKLF-ZZA-201304). We also

534 thank Chinese Research Council scholarship program for providing funding for

535 Xingfeng $\mathrm{Xu}$. This material was also partly based upon work supported by the

536 Cooperative State Research, Extension, Education Service, USDA, Massachusetts

537 Agricultural Experiment Station (MAS00491) and USDA, NRI Grants (2011-67021, 538 2013-03795, and 2014-67021).

\section{References}

542 Adjonu, R., Doran, G., Torley, P., \& Agboola, S. (2014). Whey protein peptides as components of nanoemulsions: a review of emulsifying and biological functionalities. Journal of Food Engineering, 122, 15-27. 
Barac, M., Cabrilo, S., Stanojevic, S., Pesic, M., Pavlicevic, M., Zlatkovic, B., \& Jankovic, M. (2012). Functional properties of protein hydrolysates from pea (Pisum sativum, L) seeds. International Journal of Food Science \& Technology, 47(7), 1457-1467.

Charoen, R., Jangchud, A., Jangchud, K., Harnsilawat, T., Naivikul, O., \& McClements, D. J. (2011). Influence of biopolymer emulsifier type on formation and stability of rice bran oil-in-water emulsions: whey protein, gum arabic, and modified starch. Journal of Food Science, 76(1), E165-E172.

Cheetangdee, N., \& Benjakul, S. (2015). Antioxidant activities of rice bran protein hydrolysates in bulk oil and oil-in-water emulsion. Journal of the Science of Food and Agriculture, 95, 1461-1468.

Cui, C., Zhao, M., Yuan, B., Zhang, Y., \& Ren, J. (2013). Effect of pH and pepsin limited hydrolysis on the structure and functional properties of soybean protein hydrolysates. Journal of Food Science, 78(12), C1871-C1877.

Damodaran, S. (2007). Amino acids, peptides, and proteins. In S. Damodaran, K. L. Parkin \& O. R. Fennema (Eds.), Fennema's food chemistry (Fourth ed., pp. 217). Boca Raton, FL.: CRC Press.

Damodaran, S., Parkin, K. L., \& Fennema, O. R. (2007). Fennema's Food Chemistry (Fourth ed.). Boca Raton, FL.: CRC Press.

Dickinson, E. (2003). Hydrocolloids at interfaces and the influence on the properties of dispersed systems. Food Hydrocolloids, 17(1), 25-39.

Dickinson, E. (2011). Mixed biopolymers at interfaces: Competitive adsorption and multilayer structures. Food Hydrocolloids, 25(8), 1966-1983.

Du, Y., Jiang, Y., Zhu, X., Xiong, H., Shi, S., Hu, J., Peng, H., Zhou, Q., \& Sun, W. (2012). Physicochemical and functional properties of the protein isolate and major fractions prepared from Akebia trifoliata var.australis seed. Food Chemistry, 133(3), 923-929.

Du, Y., Shi, S., Jiang, Y., Xiong, H., Woo, M. W., Zhao, Q., Bai, C., Zhou, Q., \& Sun, W. (2013). Physicochemical properties and emulsion stabilization of rice dreg glutelin conjugated with $\kappa$-carrageenan through Maillard reaction. Journal of the Science of Food and Agriculture, 93(1), $125-133$.

Euston, S. R., Finnigan, S. R., \& Hirst, R. L. (2001). Heat-induced destabilization of oil-in-water emulsions formed from hydrolyzed whey protein. Journal of Agricultural and Food Chemistry, 49(11), 5576-5583.

García-Moreno, P. J., Batista, I., Pires, C., Bandarra, N. M., Espejo-Carpio, F. J., Guadix, A., \& Guadix, E. M. (2014). Antioxidant activity of protein hydrolysates obtained from discarded Mediterranean fish species. Food Research International, 65, 469-476.

Ghribi, A. M., Gafsi, I. M., Sila, A., Blecker, C., Danthine, S., Attia, H., Bougatef, A., \& Besbes, S. (2015). Effects of enzymatic hydrolysis on conformational and functional properties of chickpea protein isolate. Food Chemistry, 187, 322-330.

Guan, X., Yao, H., Chen, Z., Shan, L., \& Zhang, M. (2007). Some functional properties of oat bran protein concentrate modified by trypsin. Food Chemistry, 101(1), 163-170.

Hakansson, A., Tragardh, C., \& Bergenstahl, B. (2009). Studying the effects of adsorption, recoalescence and fragmentation in a high pressure homogenizer using a dynamic simulation model. Food Hydrocolloids, 23(4), 1177-1183.

Israelachvili, J. N. (2011). Intermolecular and surface forces: revised third edition: Academic press.

Jamdar, S., Rajalakshmi, V., Pednekar, M., Juan, F., Yardi, V., \& Sharma, A. (2010). Influence of degree 
of hydrolysis on functional properties, antioxidant activity and ACE inhibitory activity of peanut protein hydrolysate. Food Chemistry, 121(1), 178-184.

Jiang, L., Wang, J., Li, Y., Wang, Z., Liang, J., Wang, R., Chen, Y., Ma, W., Qi, B., \& Zhang, M. (2014). Effects of ultrasound on the structure and physical properties of black bean protein isolates. Food Research International, 62, 595-601.

Jiang, Z., Sontag-Strohm, T., Salovaara, H., Sibakov, J., Kanerva, P., \& Loponen, J. (2015). Oat protein solubility and emulsion properties improved by enzymatic deamidation. Journal of Cereal Science.

Ju, Z., Hettiarachchy, N., \& Rath, N. (2001). Extraction, denaturation and hydrophobic properties of rice flour proteins. Journal of Food Science, 66(2), 229-232.

Jung, S., Murphy, P. A., \& Johnson, L. A. (2005). Physicochemical and functional properties of soy protein substrates modified by low levels of protease hydrolysis. Journal of Food Science, 70(2), C180-C187.

Karaca, A. C., Low, N. H., \& Nickerson, M. T. (2015). Potential use of plant proteins in the microencapsulation of lipophilic materials in foods. Trends in Food Science \& Technology, 42(1), 5-12.

Kralova, I., \& Sjoblom, J. (2009). Surfactants Used in Food Industry: A Review. Journal of Dispersion Science and Technology, 30(9), 1363-1383.

Laemmli, U. K. (1970). Cleavage of structural proteins during the assembly of the head of bacteriophage T4. nature, 227(5259), 680-685.

Lam, R. S., \& Nickerson, M. T. (2013). Food proteins: A review on their emulsifying properties using a structure-function approach. Food Chemistry, 141(2), 975-984.

Li, Y., Lu, F., Luo, C., Chen, Z., Mao, J., Shoemaker, C., \& Zhong, F. (2009). Functional properties of the Maillard reaction products of rice protein with sugar. Food Chemistry, 117(1), 69-74.

Likitwattanasade, T., \& Hongsprabhas, P. (2010). Effect of storage proteins on pasting properties and microstructure of Thai rice. Food Research International, 43(5), 1402-1409.

Liu, Y., Li, X., Zhou, X., Yu, J., Wang, F., \& Wang, J. (2011). Effects of glutaminase deamidation on the structure and solubility of rice glutelin. LWT-Food Science and Technology, 44(10), 2205-2210.

Lowry, O. H., Rosebrough, N. J., Farr, A. L., \& Randall, R. J. (1951). Protein measurement with the Folin phenol reagent. The Journal of Biological Chemistry, 193(1), 265-275.

McClements, D. J. (2015). Food Emulsions: Principles, Practice, and Techniques (Third Edition ed.). Bocan Raton, FL: CRC Press.

Murray, B. S. (2002). Interfacial rheology of food emulsifiers and proteins. Current Opinion in Colloid \& Interface Science, 7(5-6), 426-431.

Ochiai, K., Kamata, Y., \& Shibasaki, K. (1982). Effect of tryptic digestion on emulsifying properties of soy protein. Agricultural and Biological Chemistry, 46(1), 91-96.

Ozturk, B., Argin, S., Ozilgen, M., \& McClements, D. J. (2015). Formation and stabilization of nanoemulsion-based vitamin E delivery systems using natural biopolymers: Whey protein isolate and gum arabic. Food Chemistry, 188, 256-263.

Ozturk, B., \& McClements, D. J. (2016). Progress in natural emulsifiers for utilization in food emulsions. Current Opinion in Food Science, 7, 1-6.

Paraman, I., Hettiarachchy, N., \& Schaefer, C. (2007). Glycosylation and deamidation of rice endosperm protein for improved solubility and emulsifying properties. Cereal Chemistry, 84(6), 593-599.

Qian, C., Decker, E. A., Xiao, H., \& McClements, D. J. (2011). Comparison of biopolymer emulsifier 
performance in formation and stabilization of orange oil-in-water emulsions. Journal of the American Oil Chemists' Society, 88(1), 47-55.

Qiu, C., Sun, W., Zhao, Q., Cui, C., \& Zhao, M. (2013). Emulsifying and surface properties of citric acid deamidated wheat gliadin. Journal of Cereal Science.

Qiu, C., Zhao, M., Decker, E. A., \& McClements, D. J. (2015). Influence of anionic dietary fibers (xanthan gum and pectin) on oxidative stability and lipid digestibility of wheat protein-stabilized fish oil-in-water emulsion. Food Research International, 74, 131-139.

Qiu, C., Zhao, M., \& McClements, D. J. (2015). Improving the stability of wheat protein-stabilized emulsions: Effect of pectin and xanthan gum addition. Food Hydrocolloids, 43, 377-387.

Roger, P. H. (2004). Determining the Fluorescence Spectrum of a Protein. Current Protocols in Protein Science.

Romero, A., Beaumal, V., David-Briand, E., Cordobes, F., Guerrero, A., \& Anton, M. (2012). Interfacial and emulsifying behaviour of rice protein concentrate. Food Hydrocolloids, 29(1), 1-8.

Salminen, H., \& Weiss, J. (2014). Electrostatic adsorption and stability of whey protein-pectin complexes on emulsion interfaces. Food Hydrocolloids, 35, 410-419.

Shabbir, M. A., Anjum, F. M., Zahoor, T., \& Nawaz, H. (2011). Electrophoretic and Functional Mapping of Indica Rice Glutelin Protein Isolates. International Journal of Food Properties, 14(6), 1375-1385.

Sponton, O. E., Perez, A. A., Carrara, C., \& Santiago, L. G. (2014). Effect of limited enzymatic hydrolysis on linoleic acid binding properties of $\beta$-lactoglobulin. Food Chemistry, 146, 577-582.

Taherian, A. R., Britten, M., Sabik, H., \& Fustier, P. (2011). Ability of whey protein isolate and/or fish gelatin to inhibit physical separation and lipid oxidation in fish oil-in-water beverage emulsion. Food Hydrocolloids, 25(5), 868-878.

Tang, C.-H., \& Liu, F. (2013). Cold, gel-like soy protein emulsions by microfluidization: Emulsion characteristics, rheological and microstructural properties, and gelling mechanism. Food Hydrocolloids, 30(1), 61-72.

Tang, C.-H., \& Ma, C.-Y. (2009). Heat-induced modifications in the functional and structural properties of vicilin-rich protein isolate from kidney (Phaseolus vulgaris L.) bean. Food Chemistry, 115(3), 859-866.

Utsumi, S. (1992). Plant food protein engineering. Advances in Food and Nutrition Research (USA).

Wilde, P. J. (2009). Emulsions and nanoemulsions using dairy ingredients. In M. Corredig (Ed.), Dairy-Derived Ingredients: Food and Nutraceutical Uses (pp. 539-564).

Xia, Y., Bamdad, F., Gänzle, M., \& Chen, L. (2012). Fractionation and characterization of antioxidant peptides derived from barley glutelin by enzymatic hydrolysis. Food Chemistry, 134(3), 1509-1518

Yin, S.-W., Tang, C.-H., Cao, J.-S., Hu, E.-K., Wen, Q.-B., \& Yang, X.-Q. (2008). Effects of limited enzymatic hydrolysis with trypsin on the functional properties of hemp (Cannabis sativa L.) protein isolate. Food Chemistry, 106(3), 1004-1013.

Yong, Y. H., Yamaguchi, S., \& Matsumura, Y. (2006). Effects of enzymatic deamidation by protein-glutaminase on structure and functional properties of wheat gluten. Journal of Agricultural and Food Chemistry, 54(16), 6034-6040.

Zarins, Z., \& Chrastil, J. (1992). Separation and purification of rice oryzenin subunits by anion-exchangeand gel-permeation chromatography. Journal of Agricultural and Food 
Chemistry, 40(9), 1599-1601.

681 Zhang, J.-B., Wu, N.-N., Yang, X.-Q., He, X.-T., \& Wang, L.-J. (2012). Improvement of emulsifying properties of Maillard reaction products from $\beta$-conglycinin and dextran using controlled enzymatic hydrolysis. Food Hydrocolloids, 28(2), 301-312.

Zhao, G., Liu, Y., Zhao, M., Ren, J., \& Yang, B. (2011). Enzymatic hydrolysis and their effects on conformational and functional properties of peanut protein isolate. Food Chemistry, 127(4), 1438-1443.

Zhao, Q., Long, Z., Kong, J., Liu, T., Sun-Waterhouse, D., \& Zhao, M. (2015). Sodium caseinate/flaxseed gum interactions at oil-water interface: Effect on protein adsorption and functions in oil-in-water emulsion. Food Hydrocolloids, 43, 137-145.

690 Zhao, Q., Selomulya, C., Xiong, H., Chen, X. D., Ruan, X., Wang, S., Xie, J., Peng, H., Sun, W., \& Zhou, Q. (2012). Comparison of functional and structural properties of native and industrial process-modified proteins from long-grain indica rice. Journal of Cereal Science, 56(3), 568-575.

Zhao, Q., Xiong, H., Selomulya, C., Chen, X. D., Zhong, H., Wang, S., Sun, W., \& Zhou, Q. (2012). Enzymatic hydrolysis of rice dreg protein: Effects of enzyme type on the functional properties and antioxidant activities of recovered proteins. Food Chemistry, 134(3), 1360-1367. hydrolysis time on the physicochemical and functional properties of corn glutelin by Protamex hydrolysis. Food Chemistry, 172, 407-415. 
Table 1 Secondary structure content of native and hydrolyzed rice glutelin ( $\mathrm{RG}$ and $\mathrm{RGH}$ ) determined by circular dichroism.

\begin{tabular}{ccccc}
\hline \multirow{2}{*}{ DH } & \multicolumn{4}{c}{ Secondary structures (\%) } \\
\cline { 2 - 5 } & $\alpha$-helix & $\beta$-sheet & $\beta$-turn & Random coils \\
\hline RG & 17.7 & 30.9 & 21.7 & 29.7 \\
0.5 & 20.6 & 24.1 & 19.2 & 36.1 \\
2 & 21.6 & 22.5 & 19.2 & 36.7 \\
6 & 22.8 & 21.1 & 17.5 & 38.6 \\
\hline
\end{tabular}


Table 2 The mean particle diamater, consistency coefficient $(\mathrm{K})$ and flow behavior index (n) of oil-in-water emulsions stabilized by native or hydrolyzed rice glutelin. Different letters in the same row for each parameter are significantly different $(p<0.05)$.

\begin{tabular}{cccccc}
\hline \multirow{2}{*}{ Samples } & \multicolumn{2}{c}{$\mathrm{K}(\mathrm{mPa} \bullet \mathrm{s})$} & & \multicolumn{2}{c}{$\mathrm{n}$} \\
\cline { 2 - 3 } \cline { 5 - 6 } & 0 day & 7 days & & 0 day & 7 days \\
\hline DH0.5 & $1.65 \pm 0.08^{\mathrm{a}}$ & $2.39 \pm 0.08^{\mathrm{b}}$ & & $0.95 \pm 0.03^{\mathrm{a}}$ & $0.93 \pm 0.02^{\mathrm{a}}$ \\
DH2 & $2.96 \pm 0.10^{\mathrm{a}}$ & $3.06 \pm 0.06^{\mathrm{a}}$ & & $0.94 \pm 0.01^{\mathrm{a}}$ & $0.94 \pm 0.01^{\mathrm{a}}$ \\
DH6 & $3.02 \pm 0.12^{\mathrm{a}}$ & $19.90 \pm 0.83^{\mathrm{b}}$ & & $0.94 \pm 0.01^{\mathrm{b}}$ & $0.67 \pm 0.01^{\mathrm{a}}$ \\
\hline
\end{tabular}




\section{Figure Captions:}

Fig. 1. Molecular weight distribution profiles of native and hydrolyzed rice glutelin ( $\mathrm{RG}$ and $\mathrm{RGH}$, respectively).

Fig. 2. SDS-PAGE profiles of RG and RGH under (a) non-reducing and (b) reducing conditions.

Fig. 3. Physicochemical properties of rice glutelin samples with different degrees of hydrolysis: (a) surface hydrophobicity; (b) intrinsic fluorescence; and (c) solubility. The values reported represent means \pm standard deviations $(n=3)$ and different superscript letters indicate significant differences $(\mathrm{P}<0.05)$.

Fig. 4 Influence of storage time on the mean particle diameter of oil-in-water emulsions stabilized by hydrolyzed rice glutelin.

Fig.5 Influence of $\mathrm{pH}$ on the characteristics of oil-in-water stabilized by hydrolyzed rice glutelin: (a) mean particle diameter; (b) ל-potential.

Fig. 6 Influence of $\mathrm{NaCl}$ on the characteristics of oil-in-water stabilized by hydrolyzed rice glutelin: (a) mean particle diameter; (b) $\zeta$-potential.

Fig. 7 Influence of temperature on the characteristics of oil-in-water stabilized by hydrolyzed rice glutelin: (a) mean particle diameter; (b) $\zeta$-potential; and (c) photographs of emulsions after 15 days storage. 


\section{Fig.1}

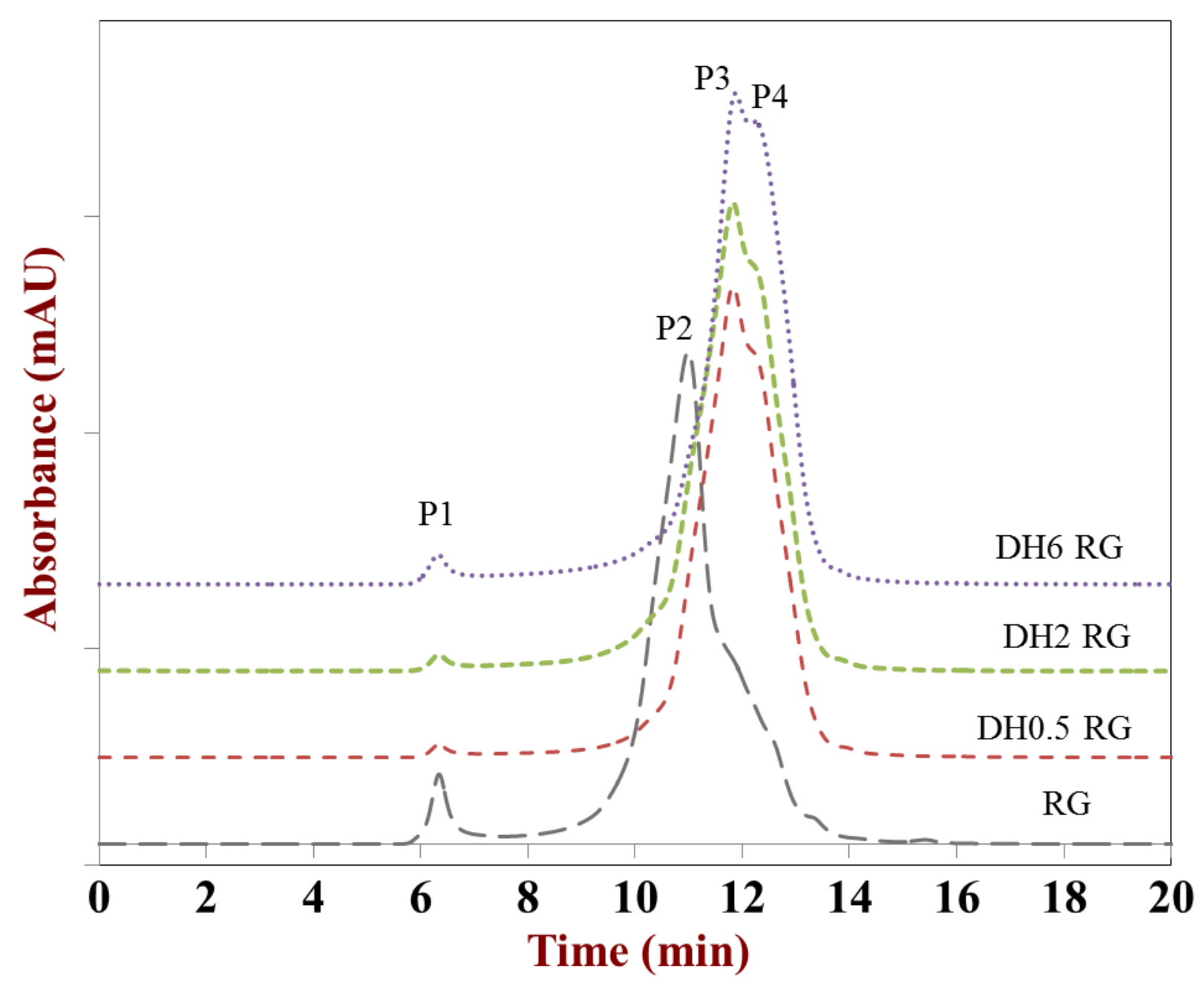

Fig.1. Molecular weight distribution profiles of native and hydrolyzed rice glutelin (RG and RGH, respectively). 
Fig.2a

(a)

$\begin{array}{lllll}\mathrm{MW}(\mathrm{kDa}) & \mathrm{DH} 0.5 & \mathrm{DH} 2 & \mathrm{DH} 6 & \mathrm{RG}\end{array}$

260

140

100

70

50

40

35

25

15

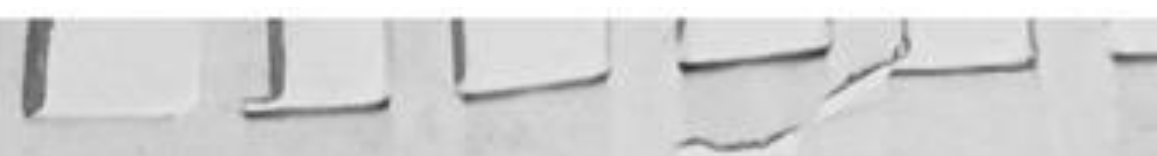

0

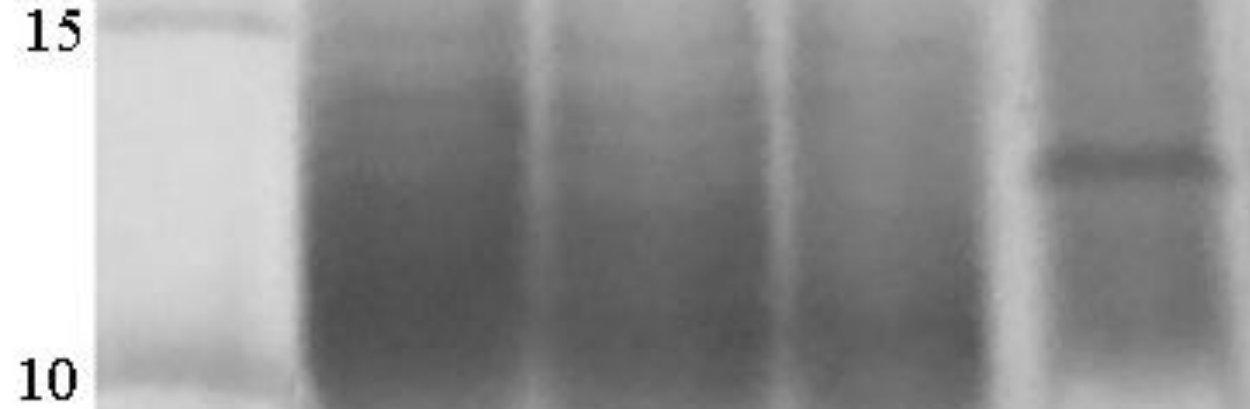

Fig.2. SDS-PAGE profiles of RG and RGH under (a) non-reducing and (b) reducing conditions. 


\section{Fig.2b}

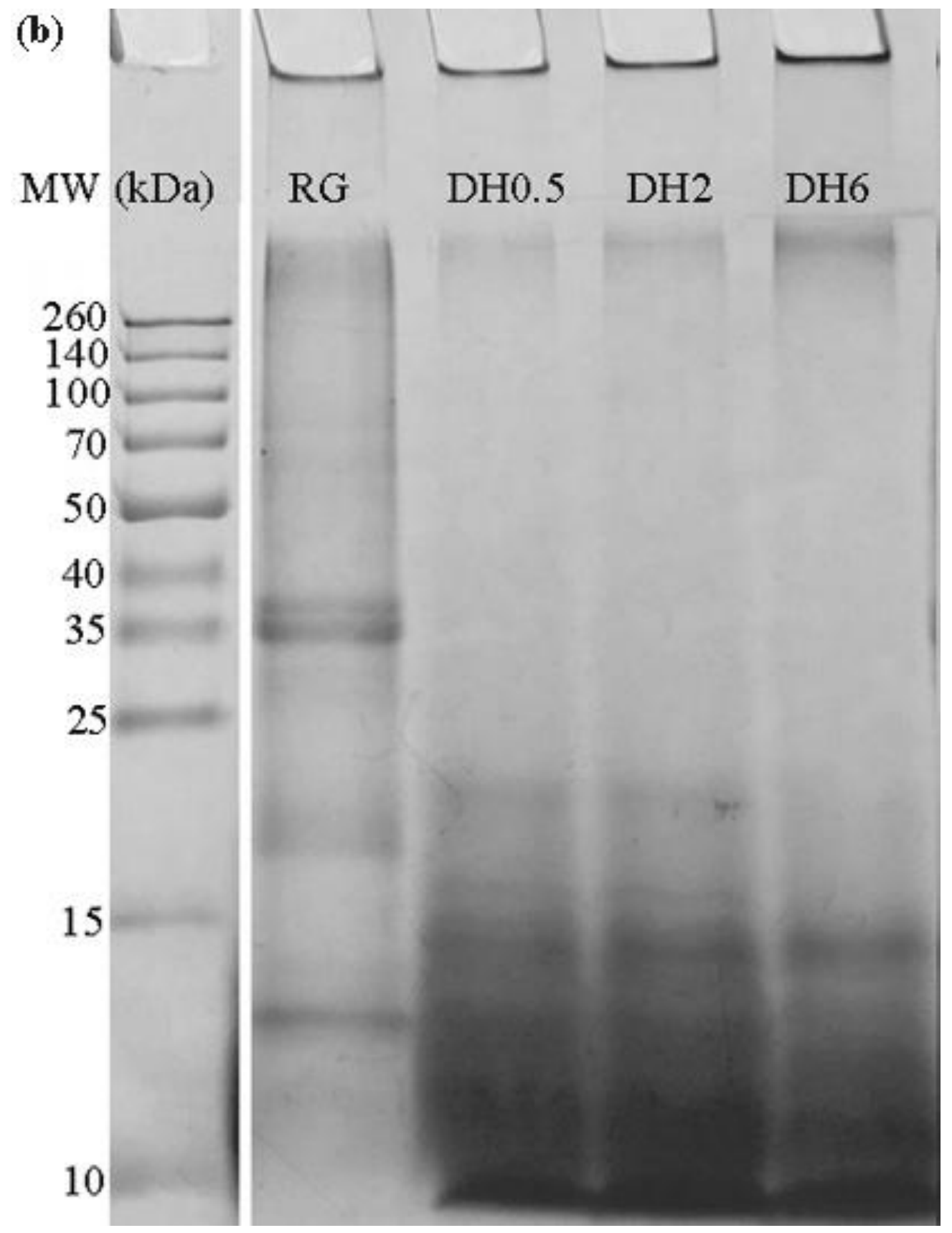

Fig.2. SDS-PAGE profiles of RG and RGH under (a) non-reducing and (b) reducing conditions. 


\section{Fig.3a.}

(a)

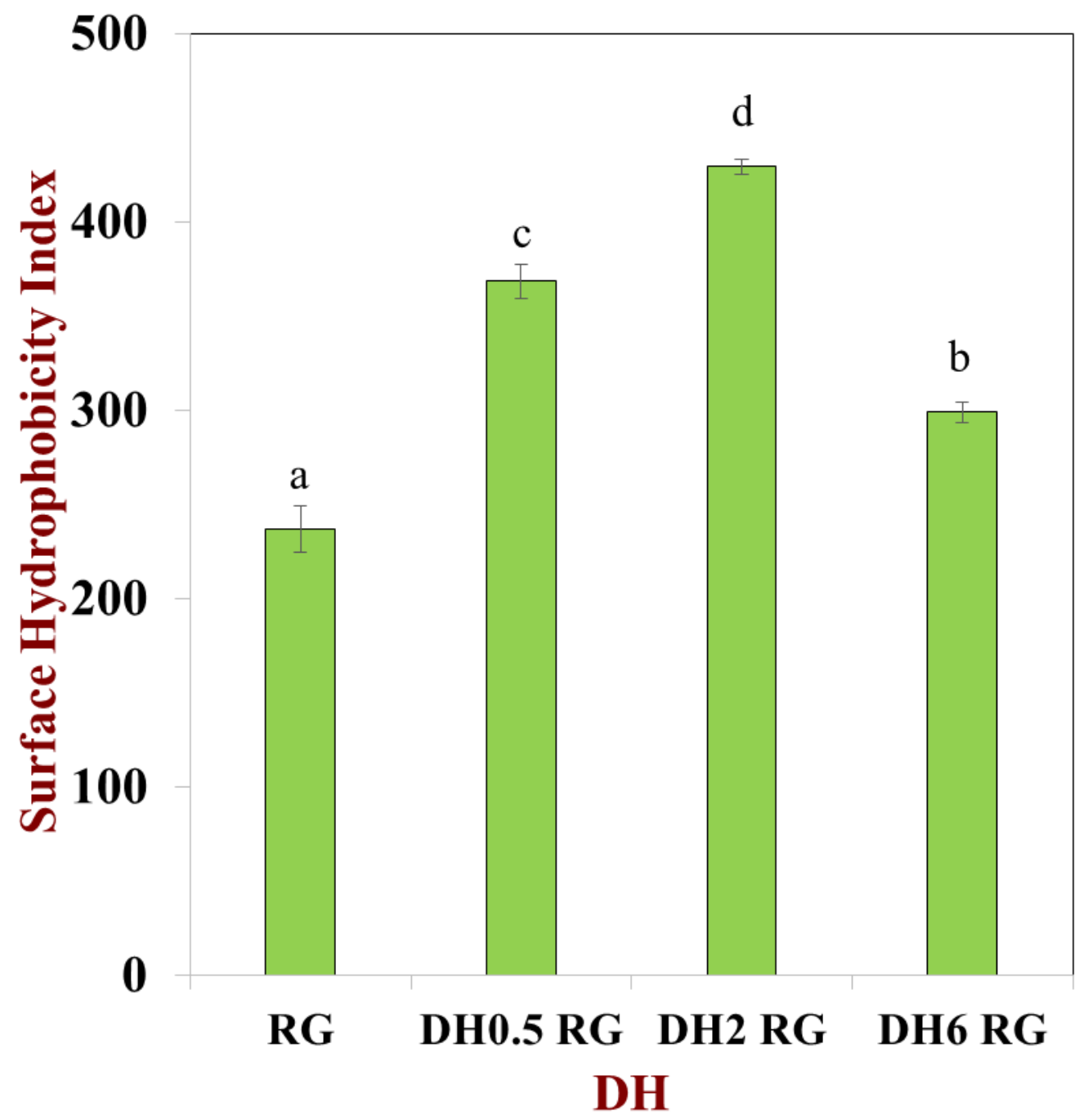

Fig.3. Surface hydrophobicity (a), intrinsic fluorescence (b), solubility (c) of RG with different $\mathrm{DH}$. The values reported represent means $(\mathrm{n}=3) \pm$ SDs and different superscript letters indicate significant difference $(\mathrm{P}<0.05)$ 
Fig.3b.

(b)

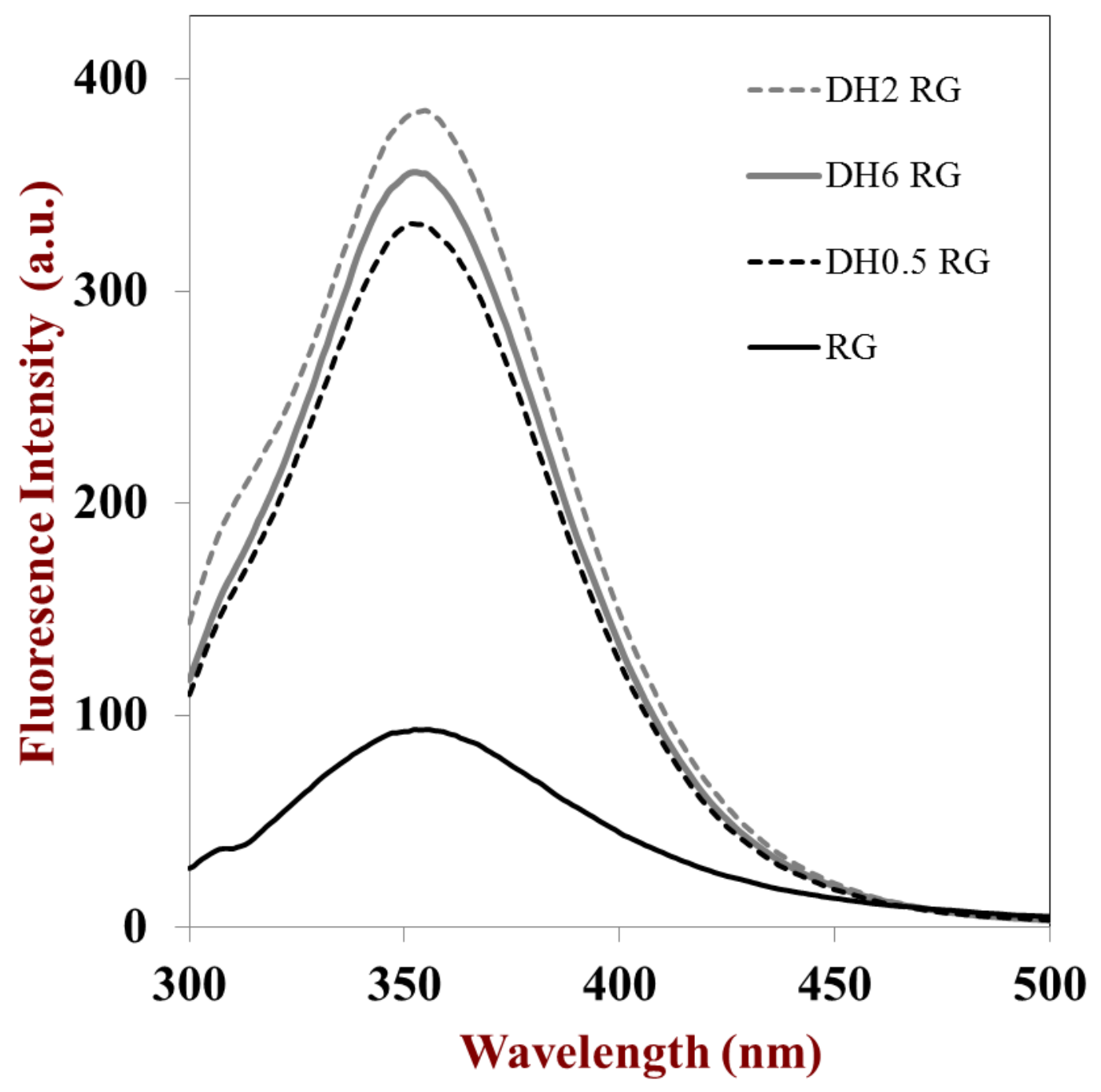

Fig.3. Surface hydrophobicity (a), intrinsic fluorescence (b), solubility (c) of RG with different DH. The values reported represent means $(n=3) \pm$ SDs and different superscript letters indicate significant difference $(\mathrm{P}<0.05)$ 
Fig.3c.

(c)

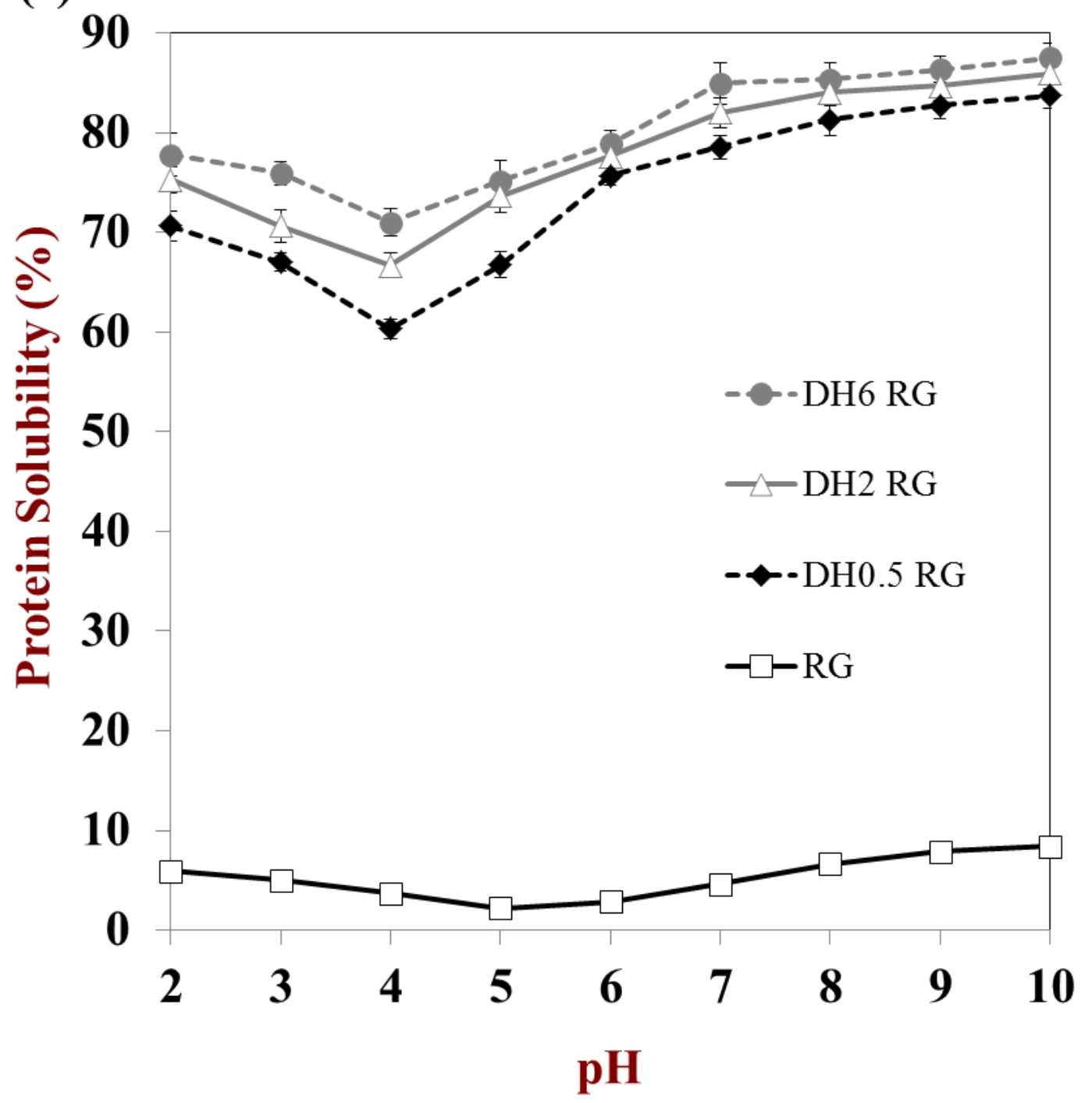

Fig.3. Surface hydrophobicity (a), intrinsic fluorescence (b), solubility (c) of RG with different $\mathrm{DH}$. The values reported represent means $(\mathrm{n}=3) \pm$ SDs and different superscript letters indicate significant difference $(\mathrm{P}<0.05)$ 
Fig.4

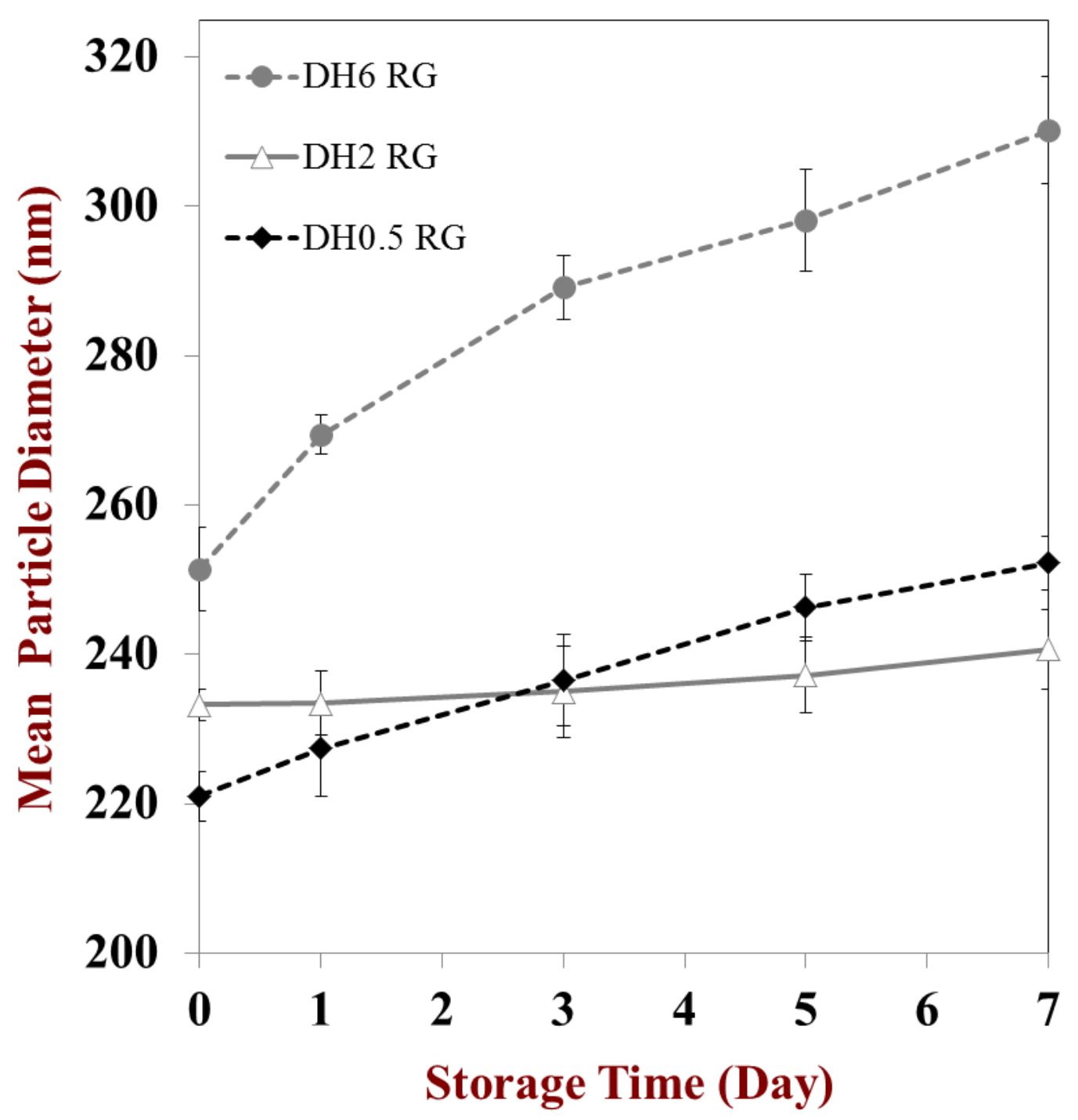

Fig.4 Influence of storage time on the mean particle size of RGH emulsion. 


\section{Fig.5a}

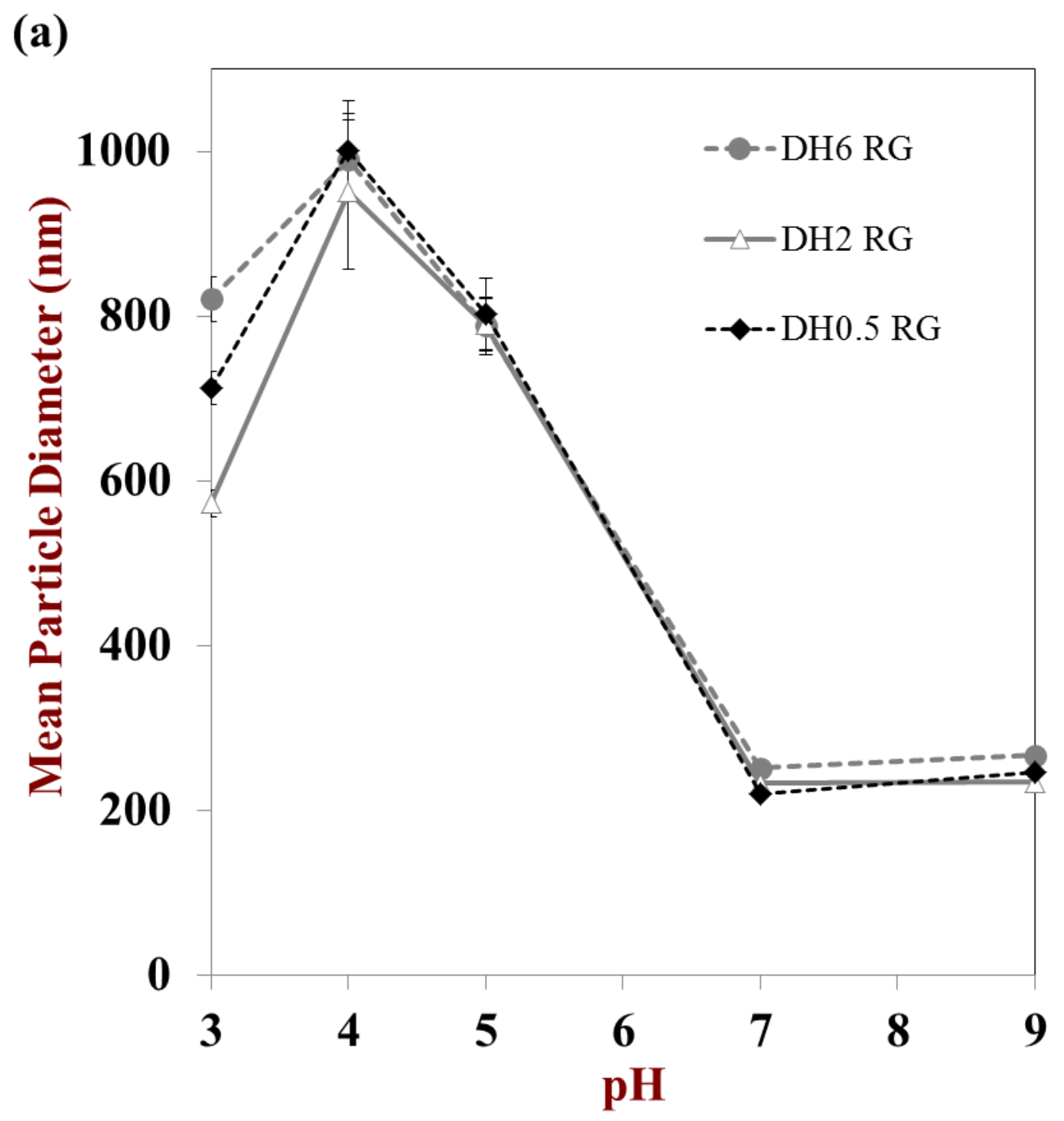

Fig.5 Influence of $\mathrm{pH}$ on the characteristics of oil-in-water RGH emulsions (a) mean particle size, (b) $\zeta$-potential. 


\section{Fig.5b}

(b)

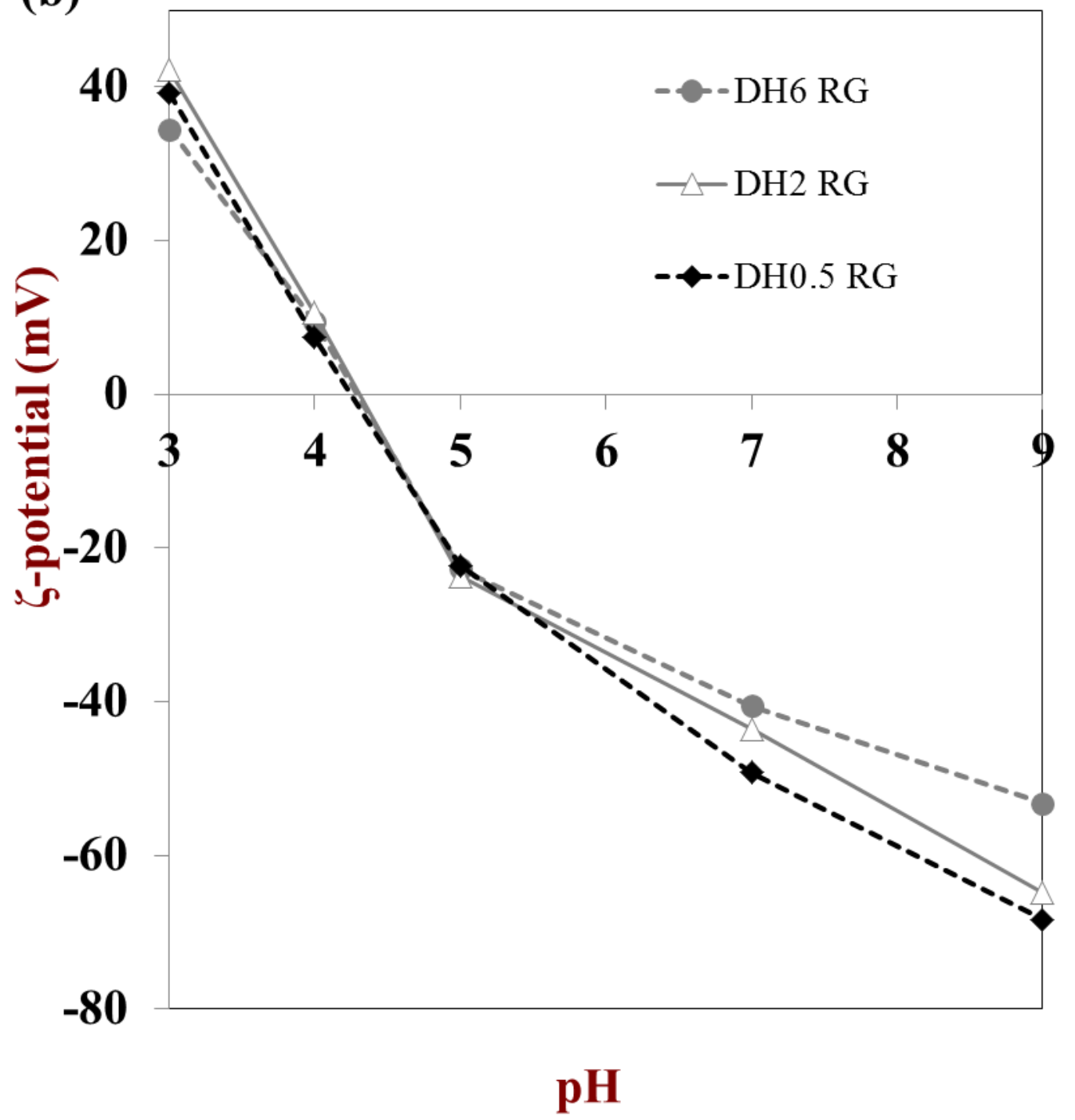

Fig.5 Influence of $\mathrm{pH}$ on the characteristics of oil-in-water RGH emulsions (a) mean particle size, (b) $\zeta$-potential. 
Fig.6a

(a)

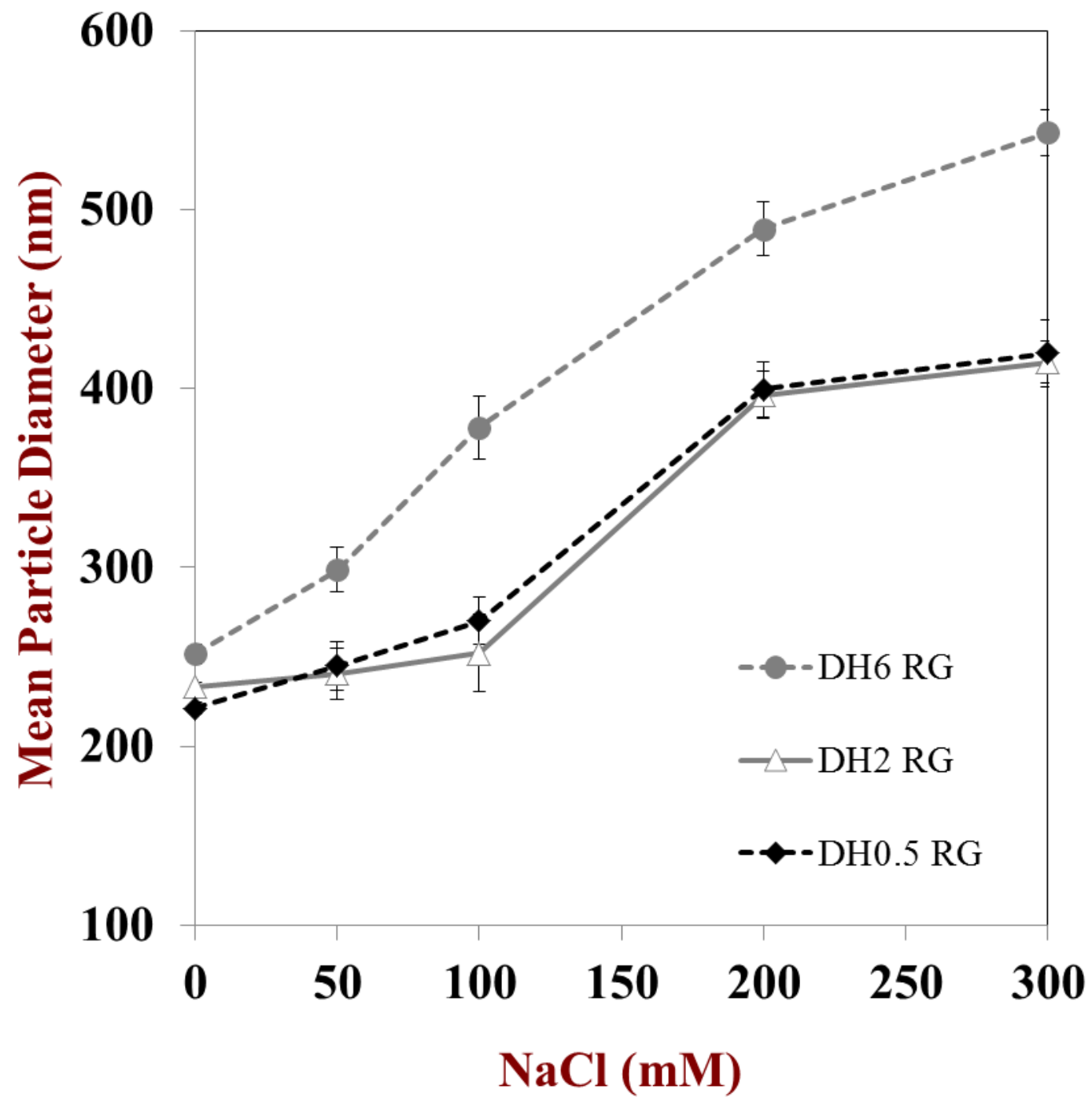

Fig.6 Influence of $\mathrm{NaCl}$ on the characteristics of oil-in-water RGH emulsions (a) mean particle size, (b) $\zeta$-potential. 


\section{Fig.6b}

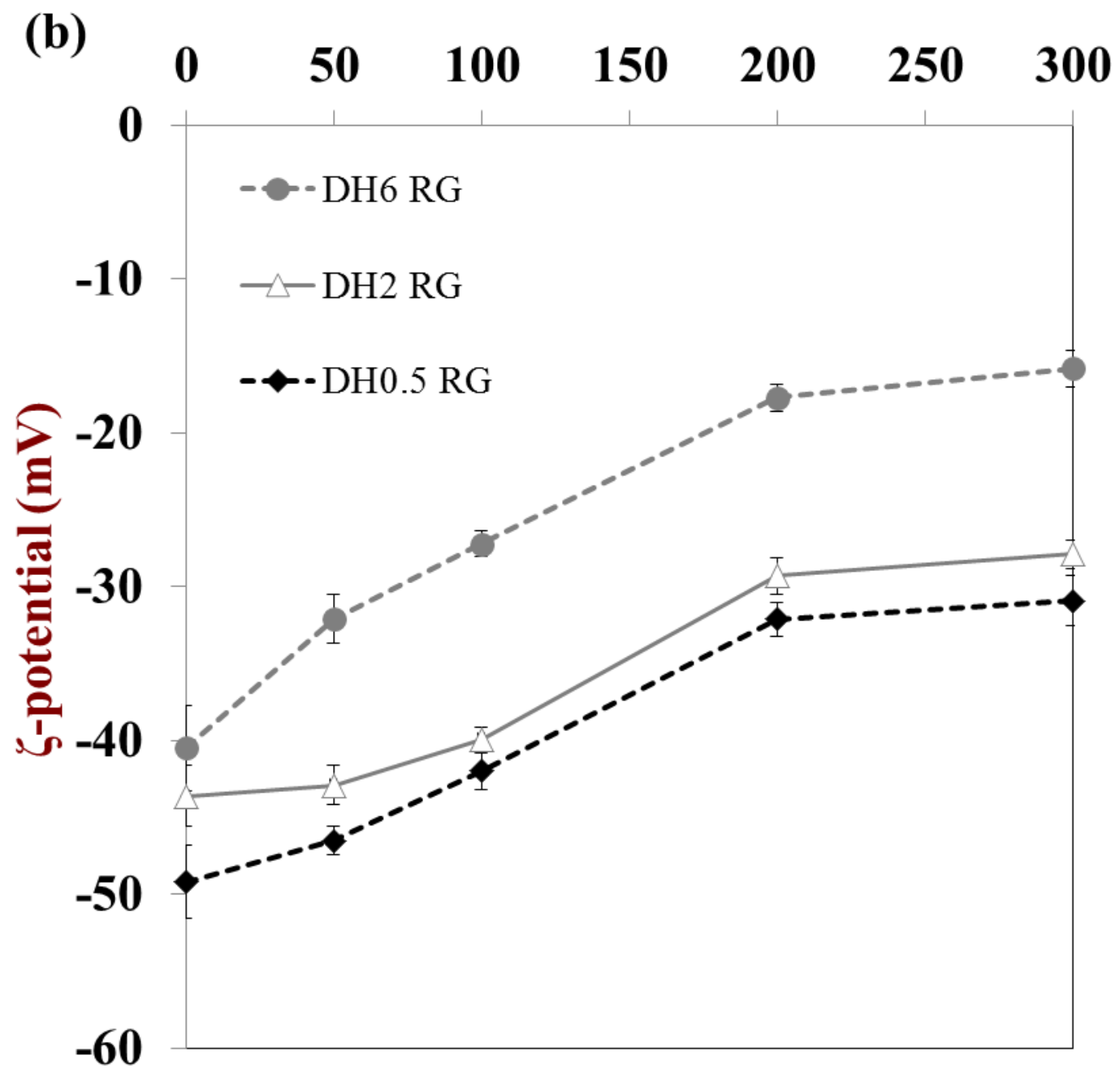

\section{$\mathrm{NaCl}(\mathrm{mM})$}

Fig.6 Influence of $\mathrm{NaCl}$ on the characteristics of oil-in-water RGH emulsions (a) mean particle size, (b) $\zeta$-potential. 


\section{Fig.7a}

(a)

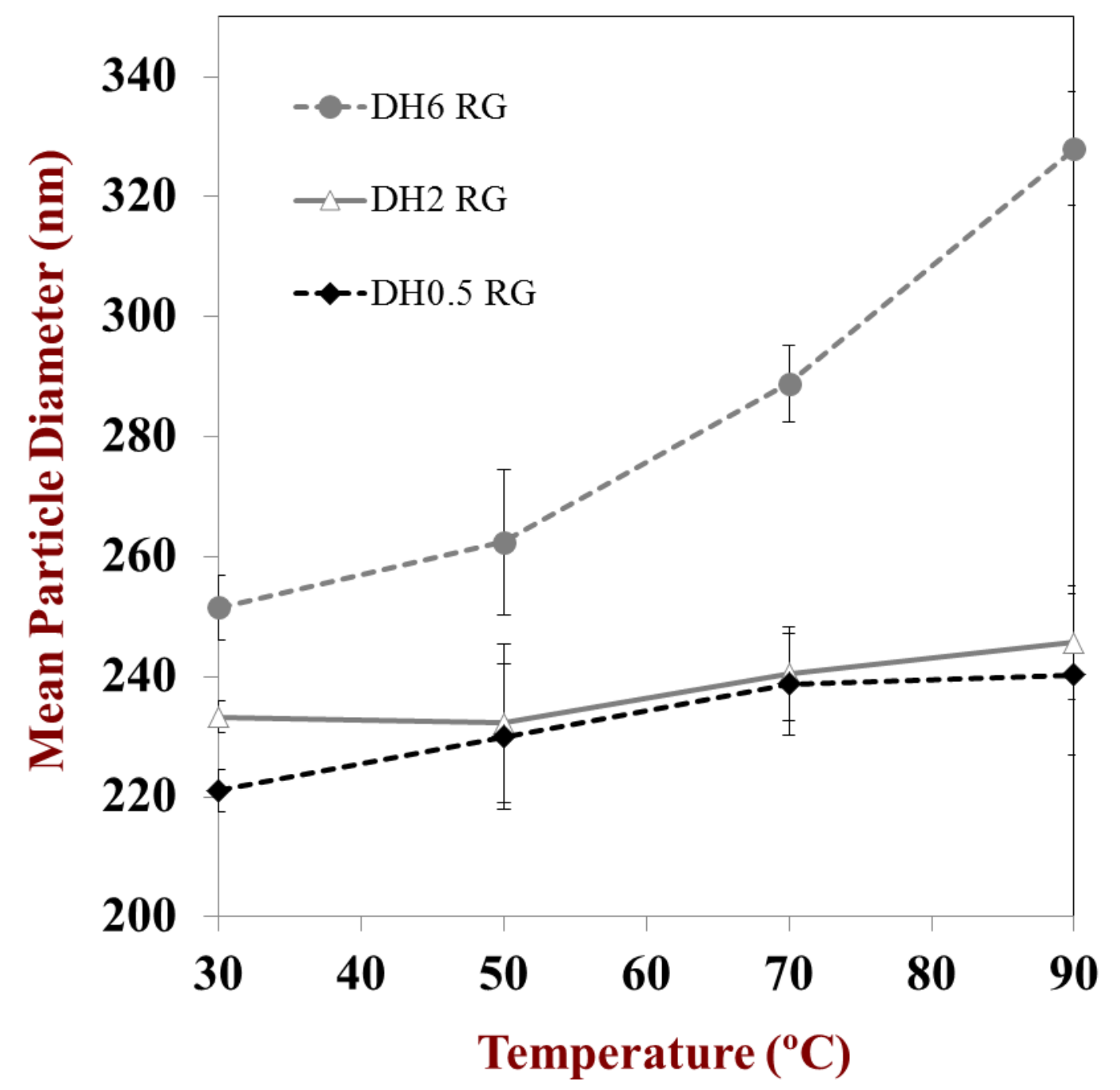

Fig.7 Influence of temperature on the characteristics of oil-in-water RGH emulsions (a) mean particle size, (b) $\zeta$-potential and (c) photographs of emulsions with different temperature after 15 days storage. 
Fig.7b

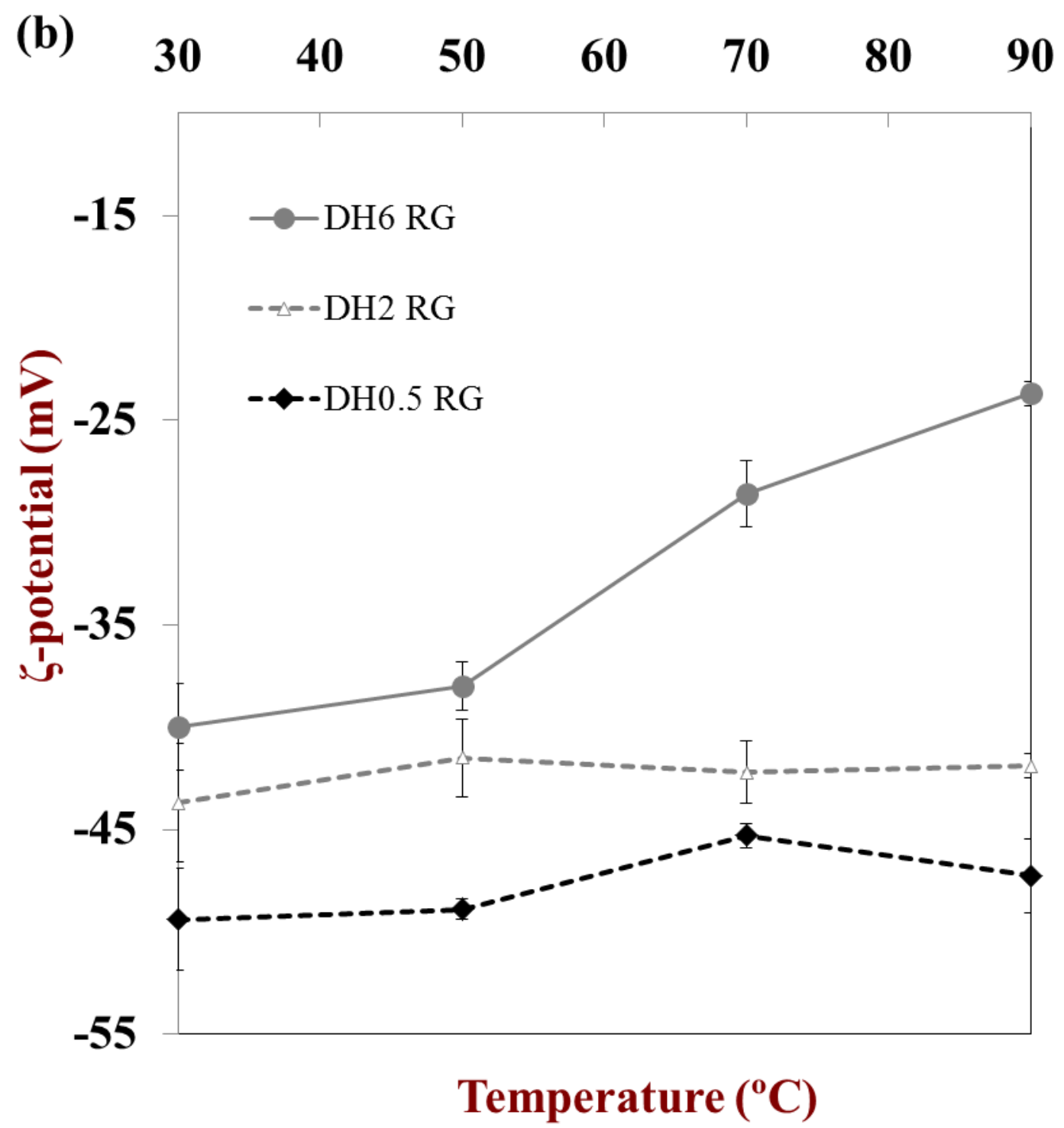

Fig.7 Influence of temperature on the characteristics of oil-in-water RGH emulsions (a) mean particle size, (b) $\zeta$-potential and (c) photographs of emulsions with different temperature after 15 days storage. 


\section{Fig.7c}

(c)
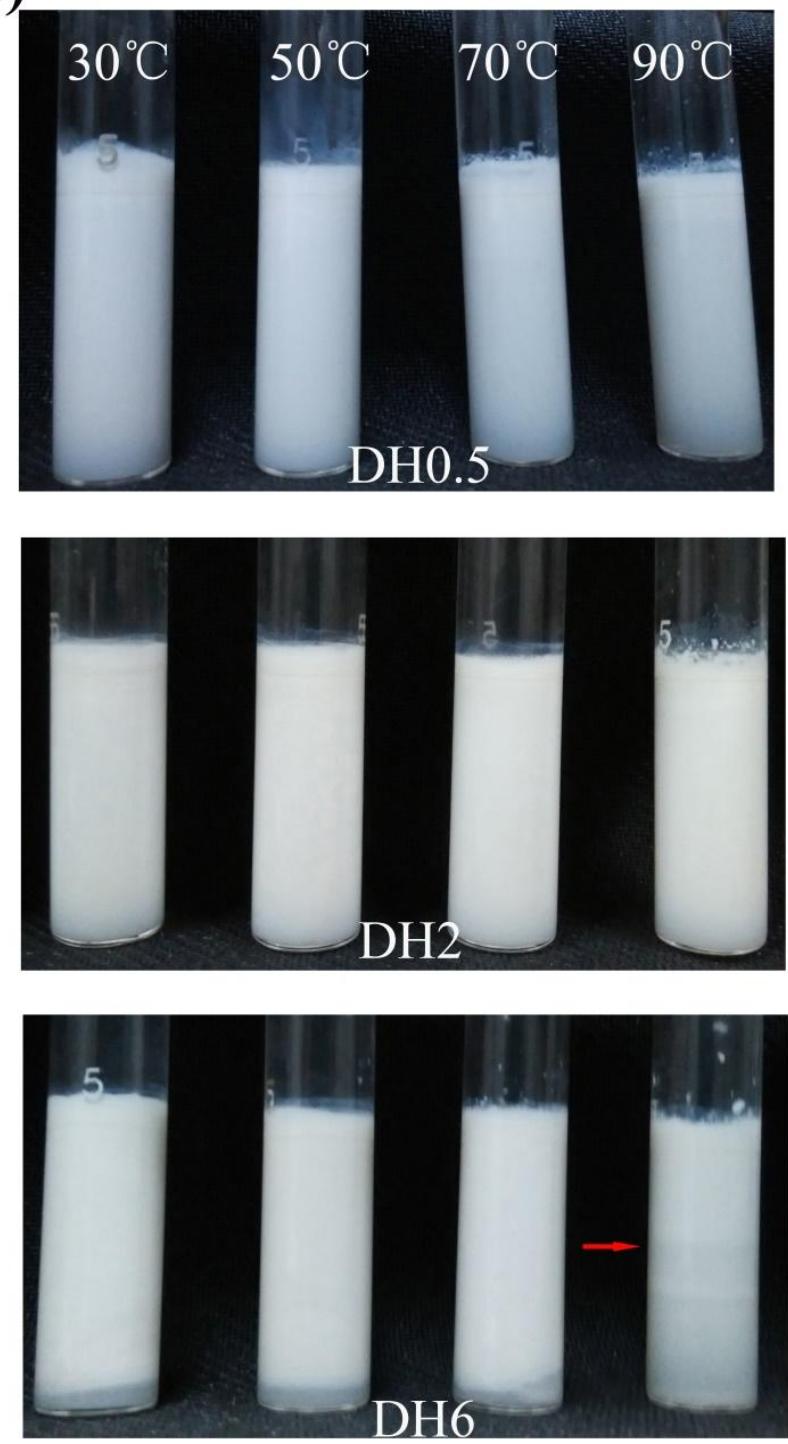

Fig.7 Influence of temperature on the characteristics of oil-in-water RGH emulsions

(a) mean particle size, (b) $\zeta$-potential and (c) photographs of emulsions with different temperature after 15 days storage. 
"Effect of limited enzymatic hydrolysis on structure and emulsifying properties of rice glutelin"

$\mathrm{Xu}$ et al

Food Hydrocolloids

\section{Graphical Abstract}

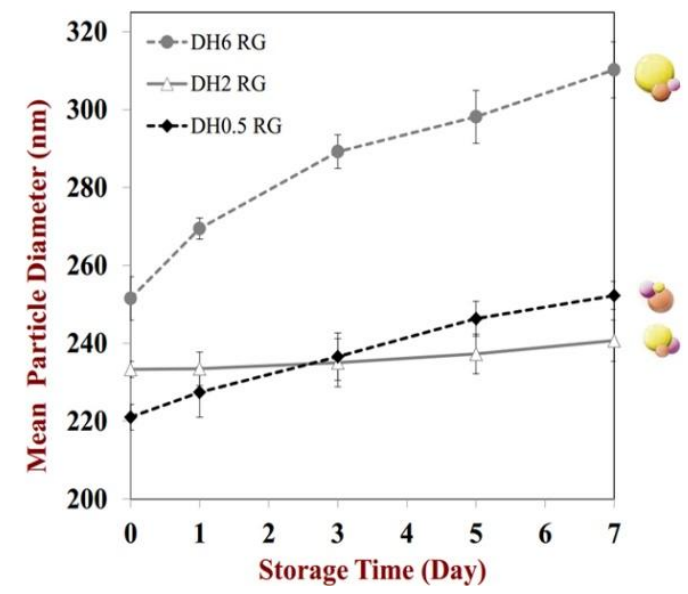

